\title{
Review Article \\ Developing Pedagogical Content Knowledge: Lessons Learned from Intervention Studies
}

\author{
Marie Evens, Jan Elen, and Fien Depaepe \\ Centre for Instructional Psychology and Technology, KU Leuven, Dekenstraat 2, Postbox 3773, 3000 Leuven, Belgium \\ Correspondence should be addressed to Marie Evens; marie.evens@ppw.kuleuven.be
}

Received 21 May 2015; Revised 16 July 2015; Accepted 27 July 2015

Academic Editor: Leonidas Kyriakides

Copyright (C) 2015 Marie Evens et al. This is an open access article distributed under the Creative Commons Attribution License, which permits unrestricted use, distribution, and reproduction in any medium, provided the original work is properly cited.

Pedagogical content knowledge (PCK) is generally accepted as positively impacting teaching quality and student learning. Therefore, research on PCK development in (prospective) teachers is highly relevant. Based on a search in three databases (ERIC, PsycInfo, and Web of Science), a systematic review is conducted on intervention studies aiming at PCK development. The research questions are threefold: (1) How are the studies designed? (2) How are the interventions designed? and (3) What elements of interventions contribute to PCK development? The results show that most intervention studies are conducted in math and science education and use a qualitative methodology. Reflection, PCK courses, contact with other teachers, and experiences in educational practice are typically part of effective interventions. The review enables the identification of clear guidelines that may strengthen future research on stimulating PCK.

\section{Introduction}

Shulman [1] introduced the concept "pedagogical content knowledge" (PCK) as a possible answer to the so-called "missing paradigm" in research and practice on teaching. Teaching was either approached by only focusing on content or by exclusively focusing on pedagogy. Shulman believed that neither approach grasped every aspect of teachers' knowledge base. Hence, he defined PCK as "that special amalgam of content and pedagogy that is uniquely the province of teachers, their own special form of professional understanding",p. 8 [2]. The two main components that Shulman [1] distinguished in PCK were, on the one hand, the most useful forms of representing the topics in one's subject area and, on the other hand, an understanding of what makes the learning of these topics easy or difficult for students. Besides PCK, he considered other categories in teachers' knowledge base, that is, content knowledge (CK), general pedagogical knowledge (PK), curriculum knowledge, knowledge of learners and their characteristics, knowledge of educational contexts, and knowledge of educational ends, purposes, and values [2].

Since Shulman's introduction of PCK, the concept has been adopted by various researchers, resulting in both theoretical developments and empirical research. Several authors elaborated Shulman's initial framework of PCK. Grossman [3], who studied PCK in the context of language, added two other components to Shulman's original PCK components, that is, knowledge of curriculum and knowledge of purposes for teaching. Another elaboration that has been very influential in the context of science education is the model of Magnusson et al. [4]. This model added three components to the original ones of Shulman, that is, orientation to teaching science (i.e., knowledge and beliefs about purposes and goals for teaching), knowledge of science curricula, and knowledge of assessment of scientific literacy. Within the context of mathematics, the model of Ball et al. [5], focusing on the concept "content knowledge for teaching mathematics" (CKTM), has been very influential. This model includes both PCK and CK, with each of these two parts being divided into three components. Concerning PCK, the model includes (1) knowledge of content and students, which is similar to Shulman's knowledge of students' (mis)conceptions, (2) knowledge of content and teaching, which is similar to Shulman's knowledge of educational representations, and (3) knowledge of curriculum. Regarding CK, the CKTM model includes (1) common content knowledge, which is mathematical knowledge that is used in other 
than educational contexts, (2) specialized content knowledge, which is mathematical knowledge that is unique to teaching contexts, and (3) knowledge at the mathematical horizon, meaning being aware of how separate mathematical topics relate to each other.

Recently, test instruments to measure teacher cognition have been developed and used in several studies, leading to empirical confirmation of Shulman's claim that PCK makes a difference for instructional quality and student learning. For instance, Baumert et al. [6] found a significant positive effect of teachers' CK and PCK on instructional quality (assessed by means of student ratings, teacher self-reports, and analyses of tasks) and on student progress in mathematics education (measured through an achievement test). Results even showed that PCK had greater predictive power for student progress and instructional quality than CK. In another study, Kunter et al. [7] confirmed these results. Moreover, they showed that teachers' PCK had a positive effect on student motivation (measured through an enjoyment questionnaire). Hence, to improve the quality of education, investing in (prospective) teachers' PCK seems to be a good strategy.

In an attempt to describe how PCK develops, several scholars have distinguished sources that contribute to PCK development $[3,8-10]$. The first source is teaching experience $[3,9,10]$. Empirical studies have shown that significant improvements in PCK are made in the early months of one's teaching career [11]. PCK courses, which aim at improving teachers' knowledge on how to teach a subject, are the second source for PCK development [3, 8]. The third PCK source is disciplinary knowledge, that is, CK $[3,9]$. Possession of CK is necessary for the presence of PCK $[9,12]$. CK positively influences teachers' decisions about the relative importance of particular subject matter and their selection and use of curriculum materials, that is, their PCK [3]. Brownlee et al. [13] showed that a course on CK had a positive influence on teachers' content knowledge for teaching mathematics, which is related to PCK. Fourthly, "apprenticeship of observation" [14] has been distinguished as another source for PCK development $[3,8]$. Apprenticeship of observation refers to the influence of teachers' past experiences as a student on their current teaching models [3]. Unfortunately, these memories may also limit teachers to rely only on familiar curricular materials and approaches [3]. Haston and Leon-Guerrero [8] empirically showed that teachers consider their memories of past education as an important PCK source. Fifthly, teachers' cooperation with colleagues has been described as a possible source for PCK development [8, 9]. According to Kind [9], provision of a supportive working environment that encourages collaboration may benefit teachers' PCK development. Haston and Leon-Guerrero [8] empirically showed the importance of cooperation with colleagues for PCK development. Finally, the sixth possible source for PCK development is the importance of reflection on educational practice [10]. Kenney et al. [15] showed that reflection on writing assignments improved teachers' PCK.

Although several scholars have mentioned PCK sources, there is still little empirical evidence on how education can contribute to PCK development. Until now, it is unclear whether the PCK sources described above have been considered in intervention research. Furthermore, it is unclear how intervention research on PCK is mainly conducted. The significance of the present study is twofold. First, it provides an overview of intervention research on PCK without being restricted to a particular disciplinary domain. Second, as it is not very clear what elements should be incorporated in interventions in order to make them effective for PCK development, the study seeks to find out these effective elements by comparing several intervention studies. In contrast to earlier studies on PCK sources, the present study makes a systematic analysis of studies that aim to develop PCK through educational interventions. Three research questions (RQs) are addressed:

(RQ 1) How are intervention studies on PCK development designed? (the disciplinary context, the participants, and the research methods).

(RQ 2) How are interventions that aim at PCK development designed? (the PCK sources that are addressed, the location, the main actors, and whether background characteristics are taken into account).

(RQ 3) What elements of interventions that aim at PCK development are effective?

\section{Methods}

A systematic review was conducted [16] using three databases (ERIC, Web of Science, and PsycInfo) because these databases include the most high-quality and relevant educational research. The databases were browsed, based on five combinations of search terms, namely, "pedagogical content knowledge AND experiment" $(n=95)$, "pedagogical content knowledge AND experimental" ( $n=71$ ), "pedagogical content knowledge AND intervention" $(n=166)$, "pedagogical content knowledge AND development" $(n=1402)$, and "pedagogical content knowledge AND course" $(n=624)$, leading to a total of 2358 search hits. These search terms were chosen because we noticed that many different synonyms of the word "intervention" are used in educational research. Therefore, we included search terms that are often used when interventions are described. The dataset was reduced based on three criteria that are implied by the RQs. Firstly, all selected articles had to be peer-reviewed and written in English and report at least one empirical study, resulting in an exclusion of, for example, purely conceptual manuscripts. Secondly, the articles had to study the effects of an educational intervention. To define an intervention, we build on the framework of Hattie, Biggs, and Purdie [17]. We claim that interventions are educational interference that (a) differ from the educational activities that the instructor(s) involved in the study would normally organize, (b) require an outsider (e.g., the researcher) to design the intervention and study its effects, and (c) focus on the increase of a certain variable. Hattie et al. [17] included the use of an experimental design as the fourth prerequisite. This prerequisite is not included because it would limit the search results too strongly as there were only three experimental studies in the dataset. Thirdly, all selected articles had to focus on PCK. For all abstracts 
(and if necessary the full texts), one rater checked whether they met the criteria. In case of doubt, the papers in question were discussed with two other raters until consensus was reached. After application of the three criteria, 85 articles remained in the comprehensive dataset. Articles from this dataset are marked with one asterisk in the reference list.

The comprehensive dataset was used to answer RQ 1 (the design of the intervention studies). RQs 2 and 3 were based on a limited dataset of studies containing both pre- and posttests. This choice is made because studies of this kind allow for studying the effect of an intervention on PCK development instead of PCK at one particular moment. Therefore, the chances are higher that the effects that are found can be attributed to the intervention instead of extraneous factors. Since the aim of RQs 2 and 3 is to specifically focus on the effects of interventions, we decided to limit the dataset for these research questions to studies using both pre- and posttests. The 37 articles that are part of the limited dataset are marked with two asterisks in the reference list.

The analyses were similar for the three RQs. Firstly, in a within-case analysis, each article was analyzed separately [18]. The articles were summarized in a table, relating to (1) disciplinary domain, (2) participants (educational level, teaching experience, and number of participants), (3) research methods, (4) intervention (including PCK sources, location, and main actors), (5) background characteristics, and (6) main results. The first three categories pertain to RQ 1 . The last three categories cover RQs 2 and 3. A table summarizing the articles in the limited dataset can be found in Appendix. Secondly, the within-case analyses were compared with each other in a cross-case analysis [18].

When describing PCK sources addressed in the studies, we build on the literature on sources for PCK development. When designing interventions for PCK development, it is however impossible to address PCK sources in their original meaning because interventions usually cover a shorter, delineated period of time. Therefore, in the analyses of the present study, a translation of the sources is made. "Disciplinary knowledge" is understood as all activities and courses that focus on CK. The term "PCK courses" is used to describe activities and courses focusing on PCK. Interventions addressing teaching experience include teaching and trying out new insights in a real classroom. "Contact with cooperating teachers" is understood as any contact with other people, for instance, other participants and colleagues. Interventions including reflection ask participants to systematically question past events. "Observation," finally, is used to describe interventions in which attention is given to participants' prior experiences as students.

\section{Results}

3.1. Design of the Studies. In Table 1 , an overview is provided of the contexts of the intervention studies (the educational levels and the disciplinary domains) of the comprehensive dataset. Most studies pertained to primary or secondary education. Almost three-fourths of the studies focused on natural sciences, one-fourth on mathematics, and a few on other domains.
Table 2 describes the participants and whether quantitative, qualitative, or mixed methods were used. The studies in the dataset used both preservice $(n=35)$ and inservice $(n=50)$ teachers. Within the latter group, most studies used teachers with more than five years of experience or a combination of experienced and novice teachers. A distinction is made between studies using quantitative (test or survey instruments), qualitative (interviews, document review, and observations), or mixed methodology (combining quantitative and qualitative methods). The majority used qualitative research methods, mostly combining several instruments. Particularly, interviews were often used. Qualitative methods were mostly used on smaller datasets, while quantitative methods were applied to larger datasets. All studies measured the effects of the intervention immediately after the intervention; none of the studies used retention tests to measure the effects of the intervention in the long run.

3.2. Design of the Interventions. The following paragraphs focus on the limited dataset, including only studies using both pre- and posttests, because these designs allow for grasping the effects caused by the interventions instead of extraneous factors. Three aspects are described, that is, the PCK sources that are addressed, the location of the interventions, and the main actors in the interventions.

3.2.1. Sources. The classification of PCK sources described above is used (teaching experience, PCK courses, disciplinary knowledge, observation, cooperation with colleagues, and reflection). An overview of the PCK sources in the interventions is provided in Table 3. Observation, despite being described as a PCK source by Grossman [3] and Haston and Leon-Guerrero [8], is not included in the table as no study addressed this source. Most studies covered a variety of PCK sources. PCK courses are the most common PCK source among the different interventions $(n=34)$. The contents of these courses vary across the studies, for instance, sorting tasks according to difficulty [19], an online professional development program including PCK exercises [20], or designing of a lesson plan [21]. Most interventions addressing PCK courses focused on Shulman's [1] two components: knowledge of students' (mis)conceptions and knowledge of educational representations. Particularly, teachers' knowledge of student understanding was very often addressed in interventions (e.g., [22, 23]), for instance, in tasks in which student work had to be analyzed (e.g., $[20,24])$. The second most used PCK source across the dataset is contact with cooperating teachers $(n=23)$. Activities addressing this source vary from online interaction with other participants [25], getting feedback from an experienced teacher [19], to group discussions [26-29]. Examples of the third most used source, teaching experience $(n=21)$, are a research project that teachers tried out in their classroom [30] or a video-based task in which lesson that was taught by the participant had to be analyzed [27]. Reflection is addressed in 17 studies. Participants reflected on learning activities (e.g., $[21,31-33])$ or on feedback from peers [24]. Reflection was mostly organized through written reports (e.g., [24, 31]). 
TABLE 1: Overview of disciplinary domains and educational levels.

\begin{tabular}{|c|c|c|c|c|c|}
\hline \multirow[b]{2}{*}{ Disciplinary domain } & \multicolumn{5}{|c|}{ Educational level } \\
\hline & Preschool education & Primary education & Secondary education & Higher education & $\begin{array}{l}\text { Combination of } \\
\text { educational levels }\end{array}$ \\
\hline \multicolumn{6}{|l|}{ Sciences } \\
\hline Chemistry & & & $\begin{array}{l}\text { De Jong and van Driel } \\
\text { [21], De Jong et al. } \\
\text { [52], Hume and Berry } \\
\text { [64], Hume }[65,66] \\
\text { Justi and van Driel } \\
\text { [26, 30], and } \\
\text { Mamlok-Naaman et } \\
\text { al. [67] }\end{array}$ & & $\begin{array}{c}\text { Khourey-Bowers and } \\
\text { Fenk [28] }\end{array}$ \\
\hline Physics & & & $\begin{array}{c}\text { Eylon and Bagno [68], } \\
\text { Halim et al. [69], and } \\
\text { Sperandeo-Mineo et } \\
\text { al. [29] }\end{array}$ & $\begin{array}{c}\text { Jang [43], Jang et al. } \\
\text { [70] }\end{array}$ & \\
\hline Biology & & & $\begin{array}{l}\text { Rozenszajn and } \\
\text { Yarden [71] }\end{array}$ & & \\
\hline General & & $\begin{array}{c}\text { Appleton [72], Beyer } \\
\text { and Davis [36], } \\
\text { Gustafson et al. [73], } \\
\text { Lee [74], Nilsson and } \\
\text { Loughran [53], } \\
\text { Nilsson and van Driel } \\
\text { [75], Nilsson [76], } \\
\text { Roth et al. [40], } \\
\text { Schneider [77], } \\
\text { Zembal-Saul et al. } \\
\text { [78], and Watters and } \\
\text { Ginns [79] }\end{array}$ & $\begin{array}{c}\text { Aydin et al., [31, 32], } \\
\text { Bertram and } \\
\text { Loughran [80], } \\
\text { Burton [24], Halai } \\
\text { and Khan [81], Hume } \\
\text { and Berry [82], } \\
\text { Kanter and } \\
\text { Konstantopoulos [27], } \\
\text { Luft et al. [42], } \\
\text { Michalsky [37], } \\
\text { Monet and Etkina } \\
\text { [46], Oshima et al. } \\
\text { [83], Park and Oliver } \\
\text { [44], van Driel et al. } \\
\text { [84], and Wahbeh and } \\
\text { Abd-El-Khalick [23] }\end{array}$ & $\begin{array}{c}\text { Dotger [85], } \\
\text { Goodnough [86], and } \\
\text { Osmonda and } \\
\text { Goodnoughb [87] }\end{array}$ & $\begin{array}{l}\text { Goodnough and } \\
\text { Hung [33], McNeill } \\
\text { and Knight [51] }\end{array}$ \\
\hline Mathematics & Tirosh et al. [88] & $\begin{array}{l}\text { Abramovich and Cho } \\
\text { [89], Capraro et al. } \\
\text { [41], Dash et al. [20], } \\
\text { Lin [90], Santagata et } \\
\text { al. [50], Strawhecker } \\
\text { [48], Tirosh [49], } \\
\text { Weber et al. [55], and } \\
\text { Imre andAkkoç [91] }\end{array}$ & $\begin{array}{c}\text { Arbaugh and Brown } \\
\text { [19], Buchholtz and } \\
\text { Kaiser [35], Davis } \\
\text { [45], Harr et al. [39], } \\
\text { Jenkins [92], Kinach } \\
\text { [54], Koellner et al. } \\
\text { [93], Leikin [94], } \\
\text { Peng [95], Seymour } \\
\text { and Lehrer [96], and } \\
\text { Watson and Beswick } \\
\text { [34] }\end{array}$ & & Derry et al. [25] \\
\hline Physical education & & $\begin{array}{c}\text { Jenkins and Veal [97], } \\
\text { Rovegno [98] }\end{array}$ & Hunuk et al. [99] & & \\
\hline Religion & $\begin{array}{c}\text { Brody and Cohen } \\
{[100]}\end{array}$ & & & & \\
\hline Social sciences & & $\begin{array}{c}\text { Henning and } \\
\text { Yendol-Hoppey [101] }\end{array}$ & & & \\
\hline Technology & & Polly [102] & $\begin{array}{c}\text { Kelani and } \\
\text { Khourey-Bowers } \\
{[103]} \\
\end{array}$ & & \\
\hline Geography & & & & & $\begin{array}{c}\text { Ormrod and Cole } \\
{[104]}\end{array}$ \\
\hline English & & $\begin{array}{l}\text { Shanahan and } \\
\text { Tochelli [105], Smith } \\
\text { and Place [106], and } \\
\text { Spear-Swerling [47] }\end{array}$ & Bentley [107] & & \\
\hline
\end{tabular}


TABLE 1: Continued.

\begin{tabular}{|c|c|c|c|c|c|}
\hline \multirow[b]{2}{*}{ Disciplinary domain } & \multicolumn{5}{|c|}{ Educational level } \\
\hline & Preschool education & Primary education & Secondary education & Higher education & $\begin{array}{l}\text { Combination of } \\
\text { educational levels }\end{array}$ \\
\hline History & & & $\begin{array}{c}\text { Achinstein and Fogo } \\
{[108]}\end{array}$ & & \\
\hline Combination & & & $\begin{array}{l}\text { Rodrigues et al. [38], } \\
\text { Williams et al. [109] }\end{array}$ & $\begin{array}{c}\text { Major and Palmer } \\
{[110]}\end{array}$ & \\
\hline Not specified & & Juang et al. [111] & & & \\
\hline
\end{tabular}

TABLE 2: Overview of participants and research designs.

\begin{tabular}{|c|c|c|c|c|c|}
\hline \multirow{3}{*}{$\begin{array}{l}\text { Number of } \\
\text { participants }\end{array}$} & \multicolumn{5}{|c|}{ Teaching experience } \\
\hline & \multirow[b]{2}{*}{ Preservice teachers } & \multicolumn{4}{|c|}{ In-service teachers } \\
\hline & & Novice teachers & $\begin{array}{l}\text { Experienced teachers } \\
\quad(>5 \text { years })\end{array}$ & $\begin{array}{c}\text { Combination of } \\
\text { novice and } \\
\text { experienced teachers }\end{array}$ & $\begin{array}{l}\text { Years of experience } \\
\text { unknown }\end{array}$ \\
\hline 1 & $\begin{array}{l}\text { Abramovich and Cho } \\
\text { [89], Halai and Khan } \\
\text { [81], and Halim et al. } \\
\text { [69] }\end{array}$ & $\begin{array}{l}\text { Jang [43]; Justi and } \\
\text { van Driel [26], } \\
\text { Osmonda and } \\
\text { Goodnoughb [87], } \\
\text { and Schneider [77] }\end{array}$ & $\begin{array}{l}\text { Goodnough [86], } \\
\text { Oshima et al. [83], } \\
\text { Seymour and Lehrer } \\
\text { [96], and Watters and } \\
\text { Ginns [79] }\end{array}$ & & Peng [95] \\
\hline $2-5$ & $\begin{array}{c}\text { Aydin et al., [31, 32], } \\
\text { Nilsson and van Driel } \\
\text { [75], Imre and Akkoç } \\
\text { [91], and Zembal-Saul } \\
\text { et al. [78] }\end{array}$ & $\begin{array}{l}\text { Achinstein and Fogo } \\
\text { [108], Justi and van } \\
\text { Driel [30], and } \\
\text { Williams et al. [109] }\end{array}$ & $\begin{array}{c}\text { Appleton [72], Park } \\
\text { and Oliver [44], and } \\
\text { Rozenszajn and } \\
\text { Yarden [71] }\end{array}$ & $\begin{array}{c}\text { Bentley [107], Jang et } \\
\text { al. [70] }\end{array}$ & Dotger [85] \\
\hline $6-10$ & $\begin{array}{l}\text { De Jong and van Driel } \\
\text { [21], Hume and Berry } \\
{[64,82], \text { Jenkins [92], }} \\
\text { Jenkins and Veal [97], } \\
\text { Rovegno [98], Smith } \\
\text { and Place [106], and } \\
\text { Weber et al. [55] }\end{array}$ & & $\begin{array}{c}\text { Bertram and } \\
\text { Loughran [80], Eylon } \\
\text { and Bagno [68], } \\
\text { Mamlok-Naaman et } \\
\text { al. [67], and } \\
\text { Shanahan and } \\
\text { Tochelli [105] }\end{array}$ & $\begin{array}{l}\text { Arbaugh and Brown } \\
\text { [19], Goodnough and } \\
\text { Hung [33], Kanter and } \\
\text { Konstantopoulos [27], } \\
\text { Koellner et al. [93], } \\
\text { Monet and Etkina } \\
\text { [46], Smith and Neale } \\
\text { [22], and Wahbeh and } \\
\text { Abd-El-Khalick [23] }\end{array}$ & Lee [74] \\
\hline $11-20$ & $\begin{array}{c}\text { Davis [45], De Jong et } \\
\text { al. [52], and Hume } \\
{[65,66]}\end{array}$ & Halim et al. [69] & van Driel et al. [84] & $\begin{array}{c}\text { Burton [24], Derry et } \\
\text { al. [25], Hunuk et al. } \\
\text { [99], and Tirosh et al. } \\
\text { [88] }\end{array}$ & $\begin{array}{c}\text { Polly [102], } \\
\text { Rodrigues et al. [38] }\end{array}$ \\
\hline $21-50$ & $\begin{array}{c}\text { Beyer and Davis [36], } \\
\text { Brody and Cohen } \\
\text { [100], Kinach [54], } \\
\text { Lin [90], Nilsson and } \\
\text { Loughran [53], } \\
\text { Nilsson [76], } \\
\text { Spear-Swerling [47], } \\
\text { Sperandeo-Mineo et } \\
\text { al. [29], and Tirosh } \\
\text { [49] }\end{array}$ & & Roth et al. [40] & & $\begin{array}{l}\text { Major and Palmer } \\
\text { [110], Watson and } \\
\text { Beswick [34] }\end{array}$ \\
\hline $51-100$ & $\begin{array}{c}\text { Harr et al. [39], } \\
\text { Henning and } \\
\text { Yendol-Hoppey [101], } \\
\text { and Strawhecker [48] }\end{array}$ & Luft et al. [42] & $\begin{array}{c}\text { Dash et al. }[20] \text {, } \\
\text { Kelani and } \\
\text { Khourey-Bowers } \\
{[103]}\end{array}$ & $\begin{array}{l}\text { McNeill and Knight } \\
\text { [51] }\end{array}$ & $\begin{array}{c}\text { Juang et al. [111], } \\
\text { Khourey-Bowers and } \\
\text { Fenk [28], Leikin } \\
\text { [94], and Santagata et } \\
\text { al. [50] }\end{array}$ \\
\hline$>100$ & $\begin{array}{c}\text { Capraro et al. [41], } \\
\text { Michalsky [37], and } \\
\text { Buchholtz and Kaiser } \\
\text { [35] }\end{array}$ & & & & $\begin{array}{l}\text { Ormrod and Cole } \\
\qquad[104]\end{array}$ \\
\hline
\end{tabular}

Note. Studies that are italic used quantitative methodology and studies in bold used mixed methods. All other studies used qualitative methods. 
TABLE 3: Overview of the PCK sources that are focused on in the interventions.

\begin{tabular}{|c|c|c|c|c|c|}
\hline Studies & $\begin{array}{l}\text { Disciplinary } \\
\text { knowledge }\end{array}$ & PCK courses & $\begin{array}{l}\text { Teaching } \\
\text { experience }\end{array}$ & $\begin{array}{c}\text { Contact with } \\
\text { cooperating teachers }\end{array}$ & Reflection \\
\hline $\begin{array}{l}\text { Justi and van Driel }[26,30] \text {, } \\
\text { Watson and Beswick }[34]\end{array}$ & $\mathrm{X}$ & $\mathrm{X}$ & $\mathrm{X}$ & $\mathrm{X}$ & $\mathrm{X}$ \\
\hline $\begin{array}{l}\text { Kanter and Konstantopoulos } \\
\text { [27], Roth et al. [40], and } \\
\text { Santagata et al. [50] }\end{array}$ & $\mathrm{X}$ & $\mathrm{X}$ & $\mathrm{X}$ & $\mathrm{X}$ & \\
\hline $\begin{array}{l}\text { Aydin et al. [31, 32], De Jong et al. } \\
\text { [52], and Smith and Neale [22] }\end{array}$ & & $\mathrm{X}$ & $\mathrm{X}$ & $\mathrm{X}$ & $\mathrm{X}$ \\
\hline $\begin{array}{l}\text { Sperandeo-Mineo et al. [29], } \\
\text { Wahbeh and Abd-El-Khalick } \\
{[23]}\end{array}$ & $\mathrm{X}$ & $\mathrm{X}$ & & $\mathrm{X}$ & $\mathrm{X}$ \\
\hline $\begin{array}{l}\text { Arbaugh and Brown [19], Derry } \\
\text { et al. [25], Jang [43], Michalsky } \\
\text { [37], and Monet and Etkina [46] }\end{array}$ & & $\mathrm{X}$ & & $\mathrm{X}$ & $\mathrm{X}$ \\
\hline $\begin{array}{l}\text { Dash et al. [20], Khourey-Bowers } \\
\text { and Fenk [28], McNeill and } \\
\text { Knight [51], and Rodrigues et al. } \\
\text { [38] }\end{array}$ & & $\mathrm{X}$ & $\mathrm{X}$ & $\mathrm{X}$ & \\
\hline $\begin{array}{l}\text { Goodnough and Hung [33], } \\
\text { Nilsson and Loughran [53] }\end{array}$ & & $\mathrm{X}$ & $\mathrm{X}$ & & $\mathrm{X}$ \\
\hline Luft et al. [42] & $\mathrm{X}$ & $\mathrm{X}$ & & $\mathrm{X}$ & \\
\hline Park and Oliver [44] & $\mathrm{X}$ & $\mathrm{X}$ & & & $\mathrm{X}$ \\
\hline Spear-Swerling [47] & $\mathrm{X}$ & $\mathrm{X}$ & $\mathrm{X}$ & & \\
\hline Strawhecker [48] & $\mathrm{X}$ & $\mathrm{X}$ & $\mathrm{X}^{\mathrm{a}}$ & & \\
\hline $\begin{array}{l}\text { Burton [24], De Jong and van } \\
\text { Driel [21] }\end{array}$ & & & $\mathrm{X}$ & & $\mathrm{X}$ \\
\hline $\begin{array}{l}\text { Buchholtz and Kaiser [35], } \\
\text { Tirosh [49], and Weber et al. [55] }\end{array}$ & $\mathrm{X}$ & $\mathrm{X}$ & & & \\
\hline Beyer and Davis [36] & & $\mathrm{X}$ & & & $\mathrm{X}$ \\
\hline Kinach [54] & & $\mathrm{X}$ & & $\mathrm{X}$ & \\
\hline Davis [45], Harr et al. [39] & & $\mathrm{X}$ & & & \\
\hline Capraro et al. [41] & & & $\mathrm{X}$ & & \\
\hline
\end{tabular}

${ }^{a}$ Only in the effective condition.

Reflective group discussions [34] were part of a few interventions. The least addressed source is disciplinary knowledge (CK) $(n=15)$. An example can be found in Buchholtz and Kaiser [35], who included a phase of content exploration in their professional development program.

3.2.2. Location. Table 4 contains the locations of the interventions and the main actors in the interventions. Concerning the locations, a distinction is made between on-site (inside a school), off-site (e.g., in a public meeting room, or at home behind a computer), or combined interventions. Most interventions were off-site $(n=18)$ or combined interventions $(n=16)$.

3.2.3. Main Actors. Only the person(s) that played the most important role (the persons from whom the participant mainly learned) in the intervention is/are mentioned in Table 4 . We made a distinction between experts, more experienced teachers, less experienced teachers, or the participants themselves. A person is classified as an expert when he/she has broad knowledge about the contents of the intervention due to experience in research. More and equally experienced teachers can be colleagues of the participant or teachers from other schools. When only the participants played a role in the intervention, the study was classified in "participants themselves." Firstly, in most studies, participants mainly learned from an expert $(n=31)$. The experts were mostly authors of the study (e.g., $[19,29,36])$. In a smaller amount of interventions, the experts were other individuals, who were trained in advance for course facilitation [20, 37, 38]. In Harr et al. [39], a computer-based learning environment was used in which the computer was the expert. Secondly, six studies included learning from equally experienced teachers. In most of these studies, participants learned from whole- or smallgroup discussions with other (equally experienced) teachers $[19,25,40]$. Furthermore, this category includes studies consisting of a course with peer review [24], a community of practice providing constant feedback and support [38], and collaborative inquiry, in which the participants answered a question through reflection and action [33]. Thirdly, in four studies, a more experienced teacher played the main 
TABLE 4: Overview of the location of the interventions and of main actors in the interventions.

\begin{tabular}{|c|c|c|c|c|}
\hline \multirow[b]{2}{*}{ Location } & \multicolumn{3}{|c|}{ Main actors } & \multirow[b]{2}{*}{ Participants themselves } \\
\hline & Expert & More experienced teacher & $\begin{array}{l}\text { Equally experienced } \\
\text { teacher }\end{array}$ & \\
\hline On-site & $\begin{array}{l}\text { Luft et al. [42] (conditions } 1 \\
\text { and 2), Rodrigues et al. [38] }\end{array}$ & Luft et al. [42] & Rodrigues et al. [38] & Park and Oliver [44] \\
\hline Off-site & $\begin{array}{c}\text { Arbaugh and Brown [19], } \\
\text { Beyer and Davis [36], } \\
\text { Buchholtz and Kaiser [35], } \\
\text { Dash et al. [20], Derry et al. } \\
\text { [25], Harr et al. [39], } \\
\text { Kinach [54], McNeill and } \\
\text { Knight [51], Michalsky [37], } \\
\text { Monet and Etkina [46], } \\
\text { Smith and Neale [22], } \\
\text { Sperandeo-Mineo et al. } \\
\text { [29], Tirosh [49], Wahbeh } \\
\text { and Abd-El-Khalick [23], } \\
\text { Watson and Beswick [34], } \\
\text { and Weber et al. [55] }\end{array}$ & $\begin{array}{c}\text { Jang [43], } \\
\text { Sperandeo-Mineo et al. } \\
\text { [29] }\end{array}$ & $\begin{array}{l}\text { Arbaugh and Brown [19], } \\
\text { Derry et al. [25] }\end{array}$ & Davis [45] \\
\hline Combination & $\begin{array}{c}\text { Aydin et al. [31, 32], De } \\
\text { Jong and van Driel [21], De } \\
\text { Jong et al. [52], Justi and } \\
\text { van Driel [26, 30], Kanter } \\
\text { and Konstantopoulos [27], } \\
\text { Khourey-Bowers and Fenk } \\
\text { [28], Nilsson and Loughran } \\
\text { [53], Roth et al. [40], } \\
\text { Santagata et al. [50], } \\
\text { Spear-Swerling [47], and } \\
\text { Strawhecker [48] }\end{array}$ & Capraro et al. [41] & $\begin{array}{c}\text { Burton [24], Goodnough } \\
\text { and Hung [33], and Roth et } \\
\text { al. [40] }\end{array}$ & \\
\hline
\end{tabular}

role: mentors gave feedback on participants' educational practice [41, 42], tutors acted as professional coaches during group activities [29], and participants met with experienced teachers to share teaching and evaluation strategies [43]. Finally, in two studies, the participants themselves played the main role, by completing a portfolio assignment on their own [44] and by using different textbooks [45].

When looking simultaneously at the main actors and the locations of the interventions, the most frequent combinations are those with an expert facilitator and an off-site location, and those with an expert facilitator and both an onsite and an off-site location.

3.2.4. Background Characteristics. Only three studies in the dataset took participants' background characteristics into account when analyzing the effects of the intervention on PCK. Davis [45] studied the impact of using two different textbooks on teachers' PCK. He concluded that teachers' beliefs about mathematics and their perceptions about textbooks (based on previous work with textbooks) had an influence on how teachers understood the lessons in the textbooks and what they learned from reading and planning from the textbooks. Harr et al. [39] expected a positive effect of participants' prior knowledge on PCK and PK and their working memory on the PCK growth caused by the intervention. However, they did not find an influence of these background characteristics on PCK development.
Wahbeh and Abd-El-Khalick [23] found a mediating effect of several background variables on PCK (i.e., CK, PK, attention to students' prior knowledge, abilities to locate, adapt, and design content-related instructional resources, and nature and attributes of science understanding).

3.3. Effective Elements in the Interventions. Comparing the results of the studies in the limited dataset, it can be concluded that the majority of the studies reported a positive effect on PCK development of the intervention. 13 out of 16 quantitative studies found a significant positive effect of their intervention on PCK development [20, 25, 27, 34, 36, 37, 3942, 46-48]. Tirosh [49] found an improvement in PCK but did not report the significance of the effect. Two quantitative studies were noneffective; their intervention did not lead to a significant effect on PCK $[35,50]$. All qualitative studies in the dataset reported a growth in PCK at the end of the intervention. For instance, Arbaugh and Brown [19] reported better performances of their participants on a PCK-related task that was executed during a postinterview in comparison with a preinterview. De Jong and van Driel [21] found that their participants mentioned more student difficulties in the postinterviews than in the preinterviews. McNeill and Knight [51] only found a growth on one particular aspect of PCK, measured by means of a test on teachers' knowledge of students' conceptions that was analyzed qualitatively using a coding scheme (i.e., on student writing, whereas no effect was 
found on classroom discussion), while all other qualitative studies found an improvement of PCK in general. 11 out of 13 studies spoke in terms of an increase in PCK $[19,21,23,26$, $29,30,33,44,45,51-53]$ while three studies found a change in the nature of their participants' PCK [31, 32, 54]. Aydin et al. [31,32] concluded that their participants moved from fragmented PCK to more integrated PCK, measured through content representations (CoRes) prepared by the participants, interviews, and reflection papers. The participants in Kinach's study [54] shifted their rather instrumental PCK into more relational PCK, which was measured by means of several documents (i.e., written journals, written homework assignments, and transcribed video-recordings of classroom discussions). All seven studies using mixed methods found an increase in PCK on their qualitative instruments. The results based on the quantitative methods differed. Two studies reported significant PCK improvement after the intervention $[28,46]$. Three studies found an increase in PCK but did not report the significance of their results $[22,38,55]$. Two studies only found a significant increase on certain subscales [24, 43]. Burton [24] found a growth in four out of five subscales, of which one was significant. Jang [43] found an increase in PCK on all four subscales, of which two were significant. These differences on the quantitative instruments show that using mixed methods leads to richer results than just focusing on one kind of methodology. The results on the qualitative measurements of these studies are nuanced by the quantitative results.

Because most studies found a positive effect of their intervention on participants' PCK and only a small contrast in research designs between effective and noneffective studies exists, identifying effective characteristics of interventions is difficult. Nevertheless, we will summarize the results for the PCK sources, the locations, and the main actors of the interventions.

3.3.1. Sources. The PCK sources mainly addressed in effective studies are reflection, PCK courses, teaching experience, and contact with cooperating teachers. Firstly, particularly reflection stands out as an effective PCK source. In Michalsky's [37] intervention, the best performing condition was the one that most strongly induced reflection. Similarly, reflection was part of 16 other effective interventions. It did not play a role in the noneffective interventions. Secondly, PCK courses were part of most effective interventions and of the noneffective interventions $[35,50]$. Several studies concluded that including PCK courses in interventions and explicitly introducing the concept PCK to the participants were beneficial for PCK development [31-33, 43, 53]. Thirdly, contact with cooperating teachers was included in 22 effective studies. Aydin et al. [31, 32] included several aspects in their intervention (such as design of content representations, microteaching, and educative mentoring) but concluded that the mentoring part was the most effective way to promote PCK. Fourthly, teaching experience was part of 20 effective studies and of the noneffective study of Santagata et al. [50]. In Strawhecker [48], the most effective conditions where those including a field experience. Similarly, De Jong and van Driel
[21] and De Jong et al. [52] used an intervention that focused on "learning from teaching" instead of "learning of teaching," meaning that participants learned in a way that involved real situations from practice that made learning more meaningful. Teaching practice seems to play an important role in the development of prospective teachers' practical knowledge base. These authors argued that preservice teachers get the opportunity in teacher education to link authentic teaching experiences to educational literature on student conceptions. Finally, disciplinary knowledge was not very often addressed in effective studies $(n=13)$ and it was part of the two noneffective studies $[35,50]$. Studies that did address disciplinary knowledge, or $\mathrm{CK}$, mostly combined it with courses or assignments on PCK (i.e., both effective and noneffective studies). For instance, the interventions of Dash et al. [20] included information related to CK and exercises related to student understanding. In Roth et al. [40], the experimental group that followed a course on CK and a program on learning to analyze educational practice through a PCK framework outperformed the control group that only took part in the content-related course.

3.3.2. Location. Almost all effective interventions took place off-site or combined off-site with on-site parts. However, noneffective interventions also mostly took place off-site or both off- and on-site.

3.3.3. Main Actors. Most effective interventions as well as most noneffective interventions were facilitated by an expert. In six effective studies, equally experienced teachers played a role. More experienced teachers were less prominent in effective interventions.

\section{Discussion and Conclusions}

This study reviewed intervention studies aiming to promote PCK development. Searching three databases (ERIC, Web of Science, and PsycInfo), a comprehensive dataset of 85 articles was used to address RQ 1: How are intervention studies on PCK development designed? A limited dataset (37 articles) was used to answer RQs 2 and 3: How are interventions that aim at PCK development designed? What elements of interventions that aim at PCK development are effective? The limited dataset only included studies with a pretest-posttest design, given the aim to examine effects of interventions.

RQ 1 aimed at giving a general overview of research on PCK interventions. Most intervention studies took place in primary and secondary natural sciences or math education, focusing on pre- and in-service teachers. The research methodology is diverse, as are sample sizes. Systematic design principles are hardly applied in designing interventions. The predominant emphasis on natural sciences and math in intervention research on PCK could be caused by the high status that society awards to these domains in comparison with other scientific domains, such as social sciences, as illustrated by the inclusion of natural sciences and math in national assessments [56]. Furthermore, there is a larger amount of general educational research on exact sciences [10]. 
A possible cause for this phenomenon might be that these domains follow a strong linear sequentiality, which makes them more delineated and thus easier to measure and to study [56].

RQ 2 compared the designs of the interventions. The most addressed PCK sources are PCK courses, contact with cooperating teachers, teaching experience, and reflection. The least addressed sources are disciplinary knowledge and observation. Most interventions took place off-site or combined off-site with on-site parts and were facilitated by an expert. Only three studies considered participants' background characteristics.

Regarding RQ 3, it was difficult to isolate effective characteristics of interventions because the dataset only included two studies that did not find a positive development. Furthermore, reported designs of effective and noneffective interventions were very similar. Nevertheless, a number of general tendencies stand out. Firstly, several PCK sources were part of effective interventions. A large number of studies showed the effectiveness of reflection for PCK development. This is interesting as in the literature on PCK sources, only van Driel and Verloop [10] identified reflection as a possible source for PCK. As Monet and Etkina [46] indicated, not all kinds of reflection are beneficial for knowledge development. Writing a lot not necessarily mirrors ample learning. Only reflection that induces higher order thinking seems beneficial. This makes teachers understand their own learning process, allowing them to apply adequate techniques in their teaching practices [46]. The importance of reflection for PCK development is also mentioned by van Driel and Berry [57]. These authors claim that, in order to promote PCK development, teacher education should be closely aligned to teaching practice and hence should include the possibility for preservice teachers to try out what they have learned and to reflect on their experiences both individually and collectively. Reflection is also considered important for teacher education in general by many scholars. For instance, McIntyre [58] claimed that reflection is important in teacher education for two main reasons: (1) it promotes preservice teachers' understanding of their own problems and needs and guides their search for solutions for these problems, and (2) it helps to develop reflection skills and habits that will be extremely useful once preservice teachers become more experienced in teaching. Furthermore, the importance of reflection has been shown empirically (e.g., [13, 59]). Brownlee et al. [13], for instance, found that students taking part in a teacher education program focusing on reflection showed more growth in sophisticated epistemological beliefs than a control group taking part in a more traditional, subject-oriented program.

PCK courses were also part of several effective interventions. Most of these interventions included courses or assignments on both student understanding and representations of subject matter. Roth et al. [40] stressed the importance of these two aspects of PCK, thereby avoiding to superficially address everything a teacher should know. Not only have PCK courses been shown to be effective in interventions but also explicitly introduced the concept PCK to the participants. This illustrates that the possibility to understand PCK as knowledge to be learned makes preservice teachers more aware of the learning process they are going through, which helps them in developing as teachers [9]. Teaching experience was part of several effective interventions. Experiences in teaching practice and contact with cooperating teachers also seem to be beneficial for PCK development.

By contrast, disciplinary knowledge was addressed less frequently in effective interventions, while it was part of both noneffective interventions. In effective interventions, it was mostly combined with PCK courses, exercises, or assignments. Hence, CK seems necessary, despite being not sufficient for PCK [12]. This does not necessarily mean that disciplinary knowledge cannot be considered as an effective PCK source. The same applies for the source "observation." Even though none of the interventions in the dataset addressed this source, observation cannot be concluded to be an ineffective PCK source.

Secondly, most effective studies took place off-site or combined off-site with on-site parts, all guided by an expert. The importance of course facilitation by experts has been shown in several studies. Chae et al. [60] found that expert tutors elicited higher learning gains on algebra problems from students than novice tutors. In Couto et al. [61], medical students considered expert course facilitators as more effective than nonexpert facilitators regarding building knowledge, guiding the learning process, achieving cognitive learning, generating learning goals, and motivating selfstudy. Furthermore, Hattie et al. [17] and Dignath et al. [62] drew similar conclusions in their meta-analyses of intervention studies on general learning skills and self-regulation. Effect sizes of intervention studies were significantly higher if the intervention was organized by researchers than if it was organized by regular teachers [62]. They claimed that researchers are more concerned with the importance of selfregulated learning. For the present study, this would mean that researchers are more aware than (either more or equally experienced) teachers about the importance of PCK and therefore better succeed in promoting it. However, not all studies in the dataset allowed for drawing this conclusion.

Thirdly, two quantitative studies in the dataset did not find positive results of their intervention, which provides a warning for future intervention research $[35,50]$. Particularly, problems in the design of the studies are pushed forward by the authors. Buchholtz and Kaiser [35] gave two possible explanations for the lack of differences in PCK between their intervention conditions and their control conditions (one consisting of preservice teachers not taking part in an intervention and one consisting of students in a nonteaching higher education program). First, the authors indicated some problems with their PCK instrument. It correlated highly with their CK test and the sample of nonteaching students (who also studied mathematics and hence had high CK scores) reached the highest results on the PCK pretest, which is problematic since PCK is considered as a kind of knowledge that is specific to the teaching profession $[1,2]$. This illustrates the need for conceptual clarity and valid operationalization of concepts. Second, the groups that were compared were not randomly selected. Each condition represented one higher education institution. The entry requirements of the 


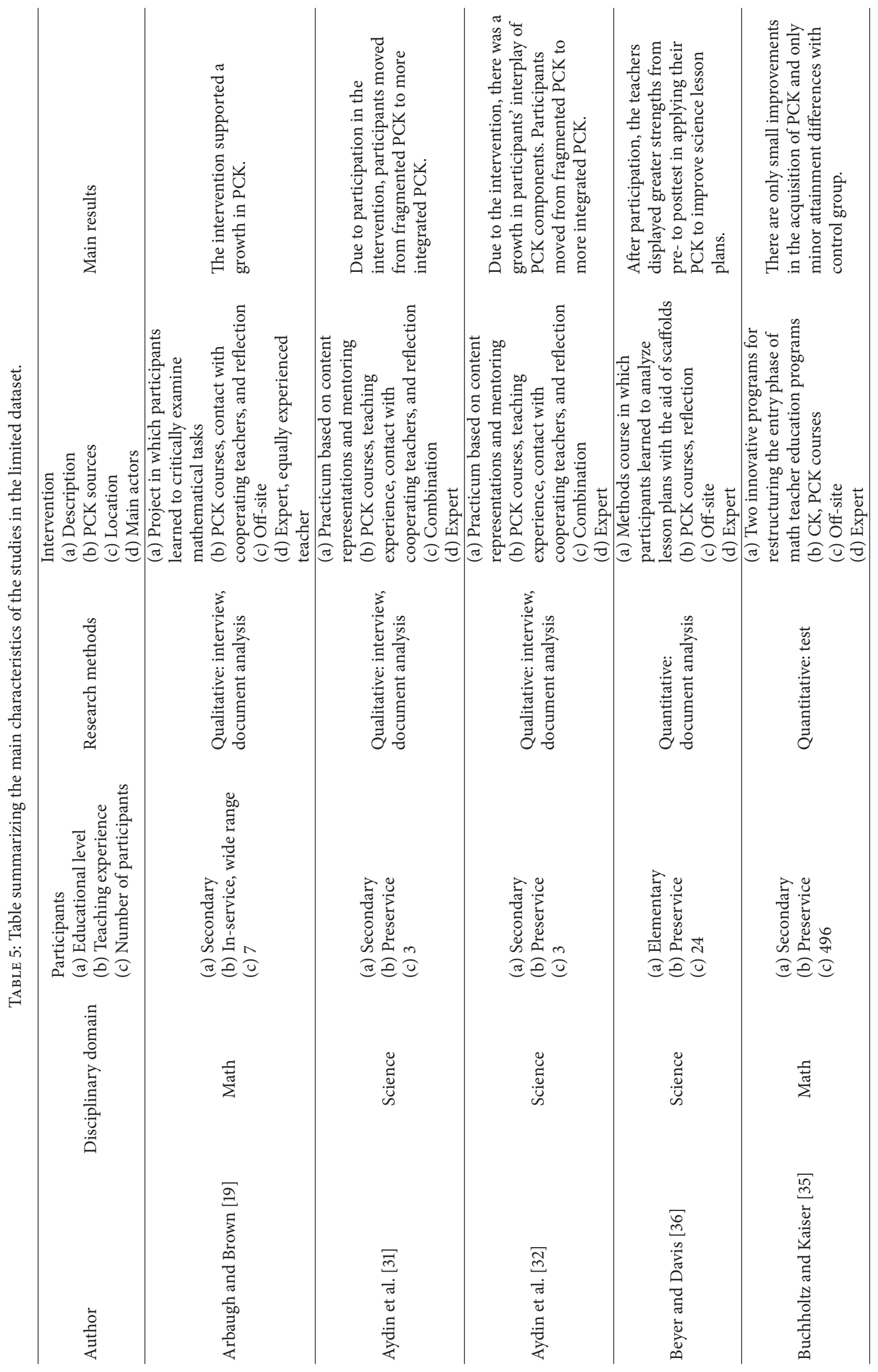




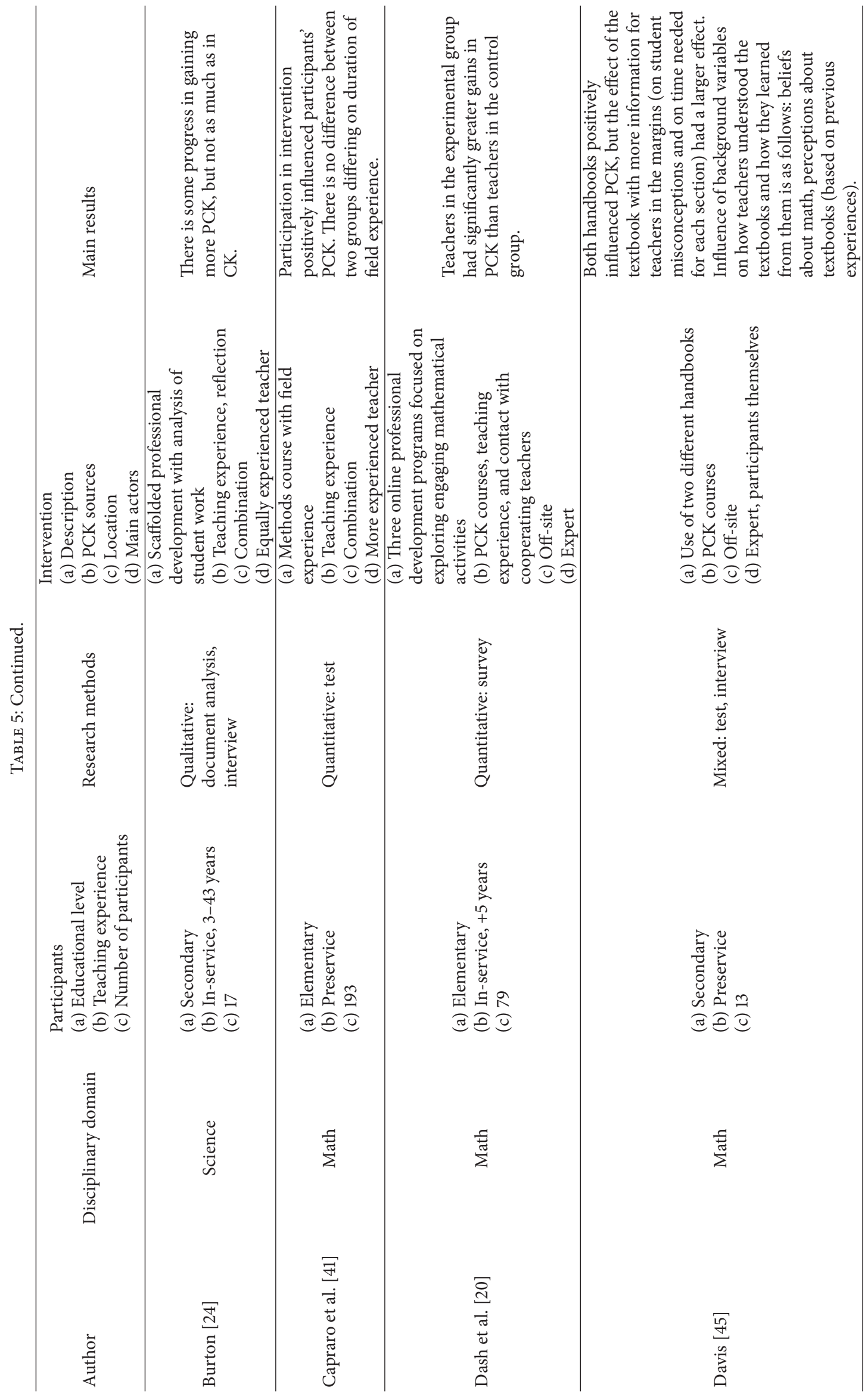




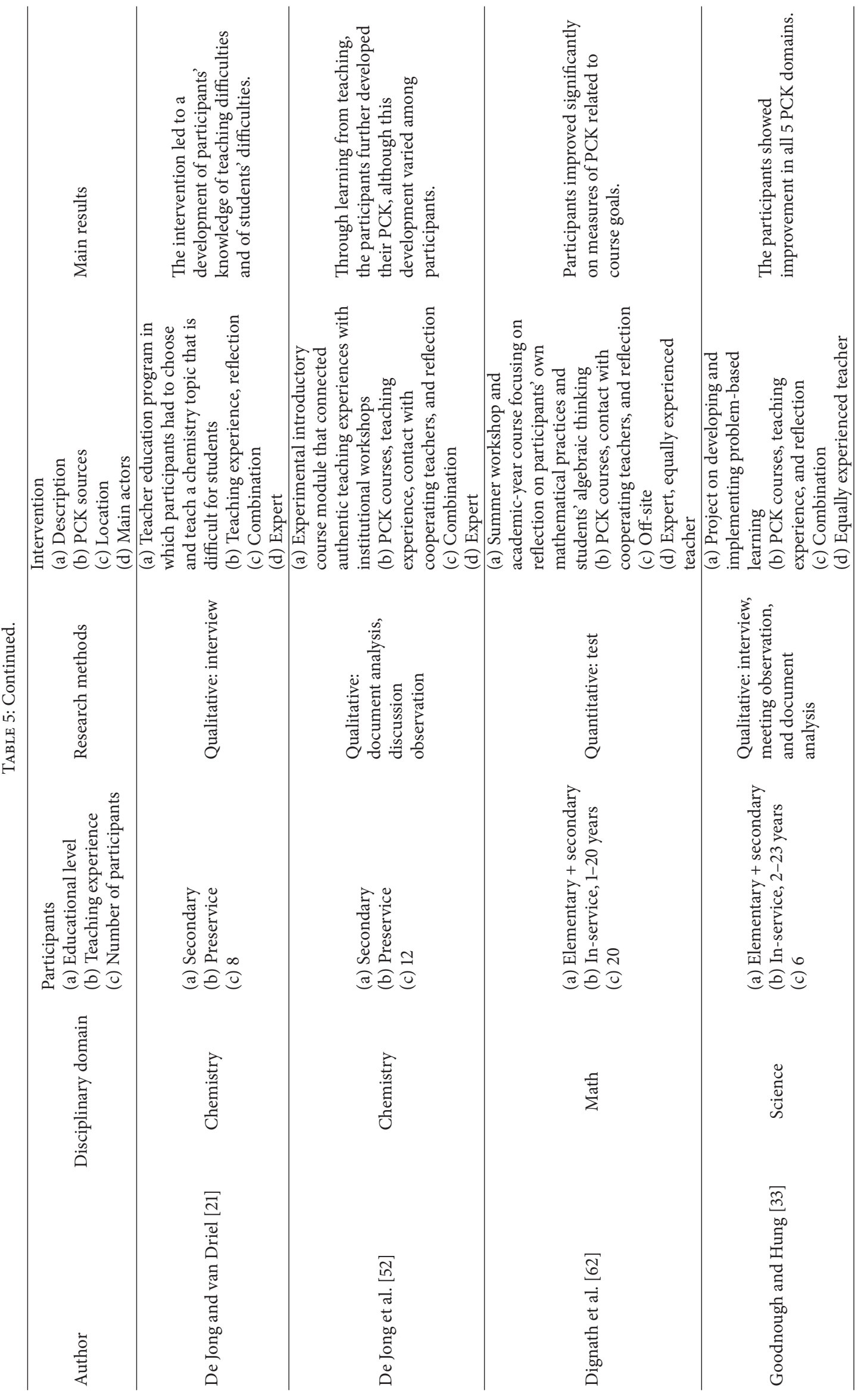




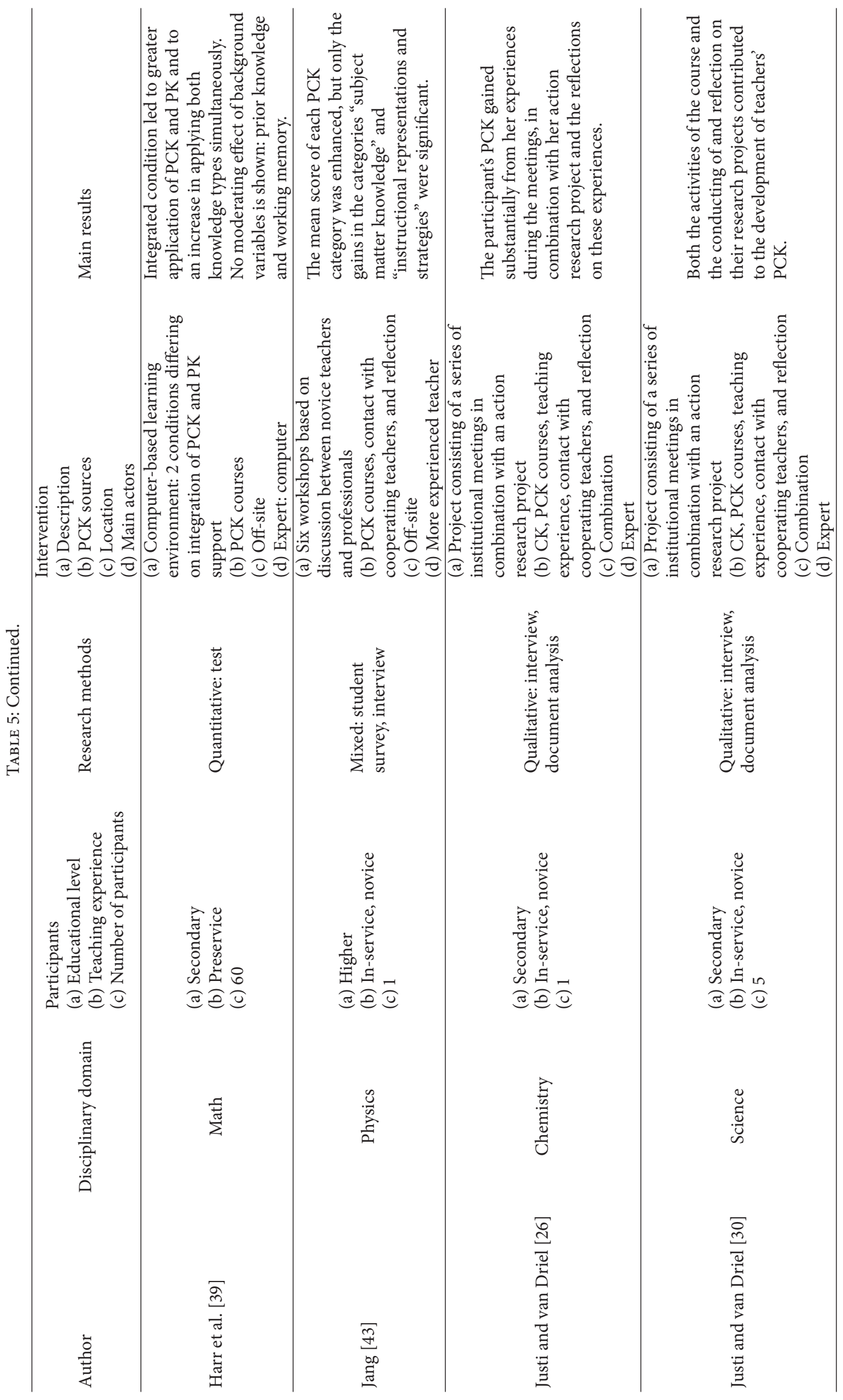




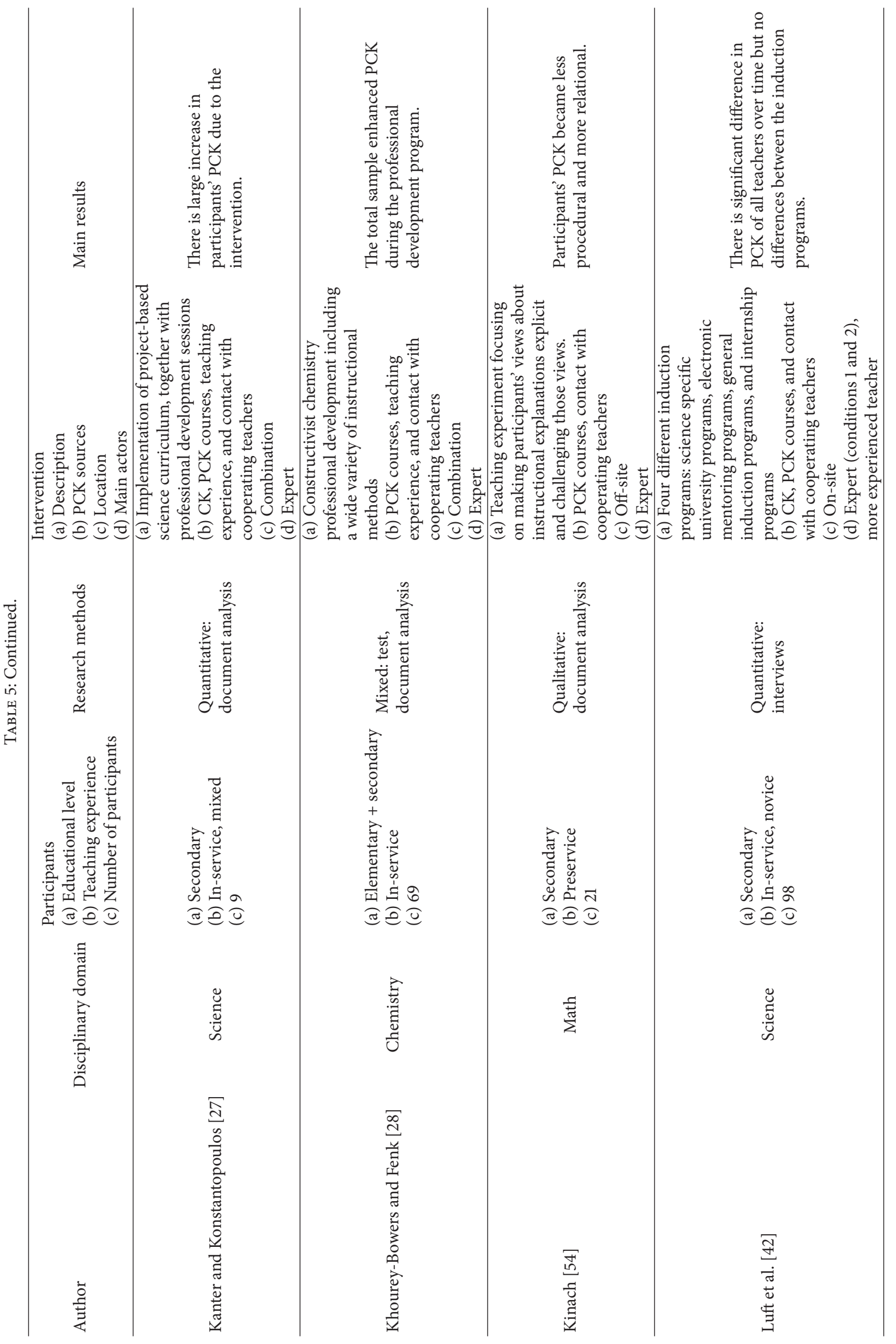




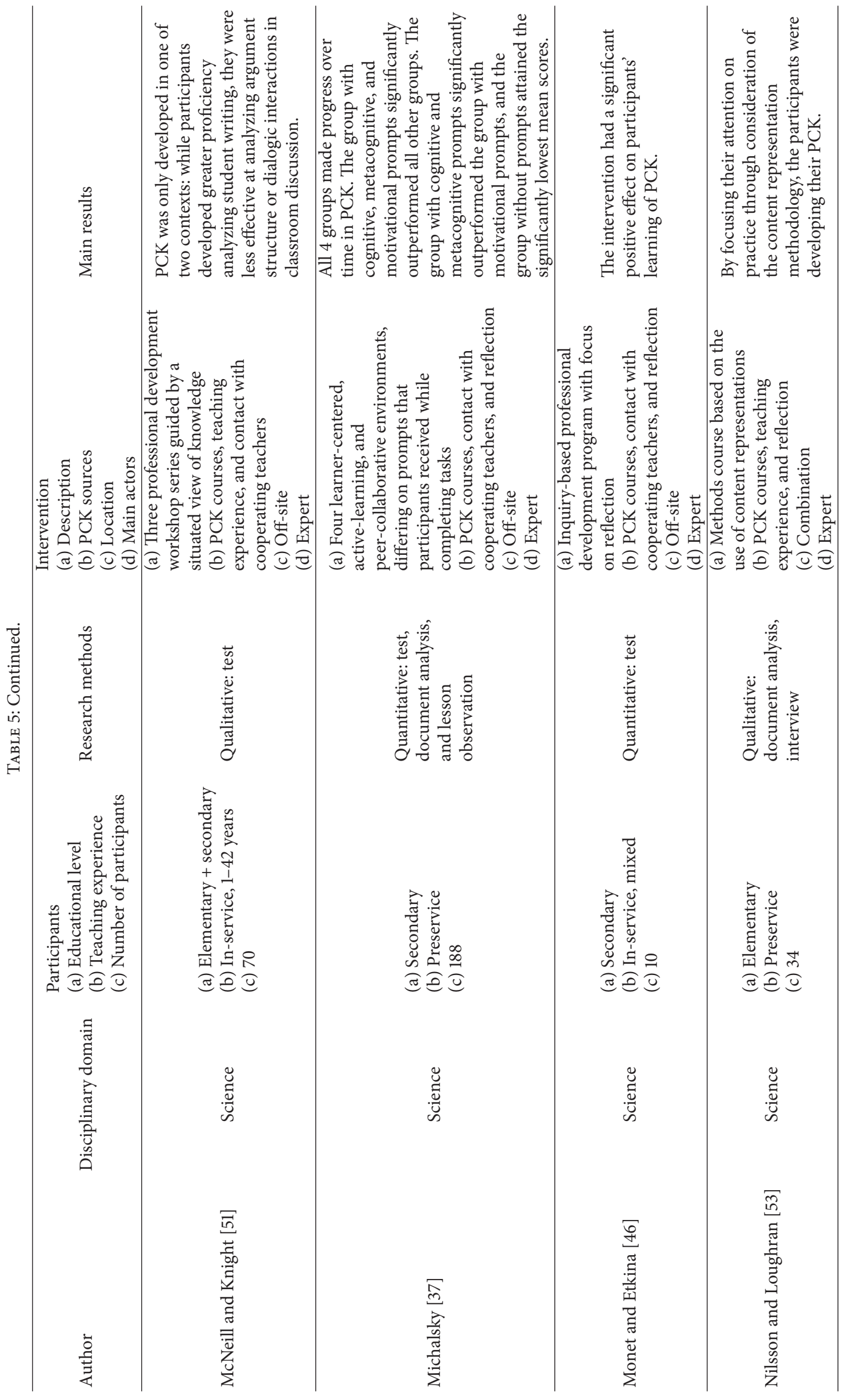




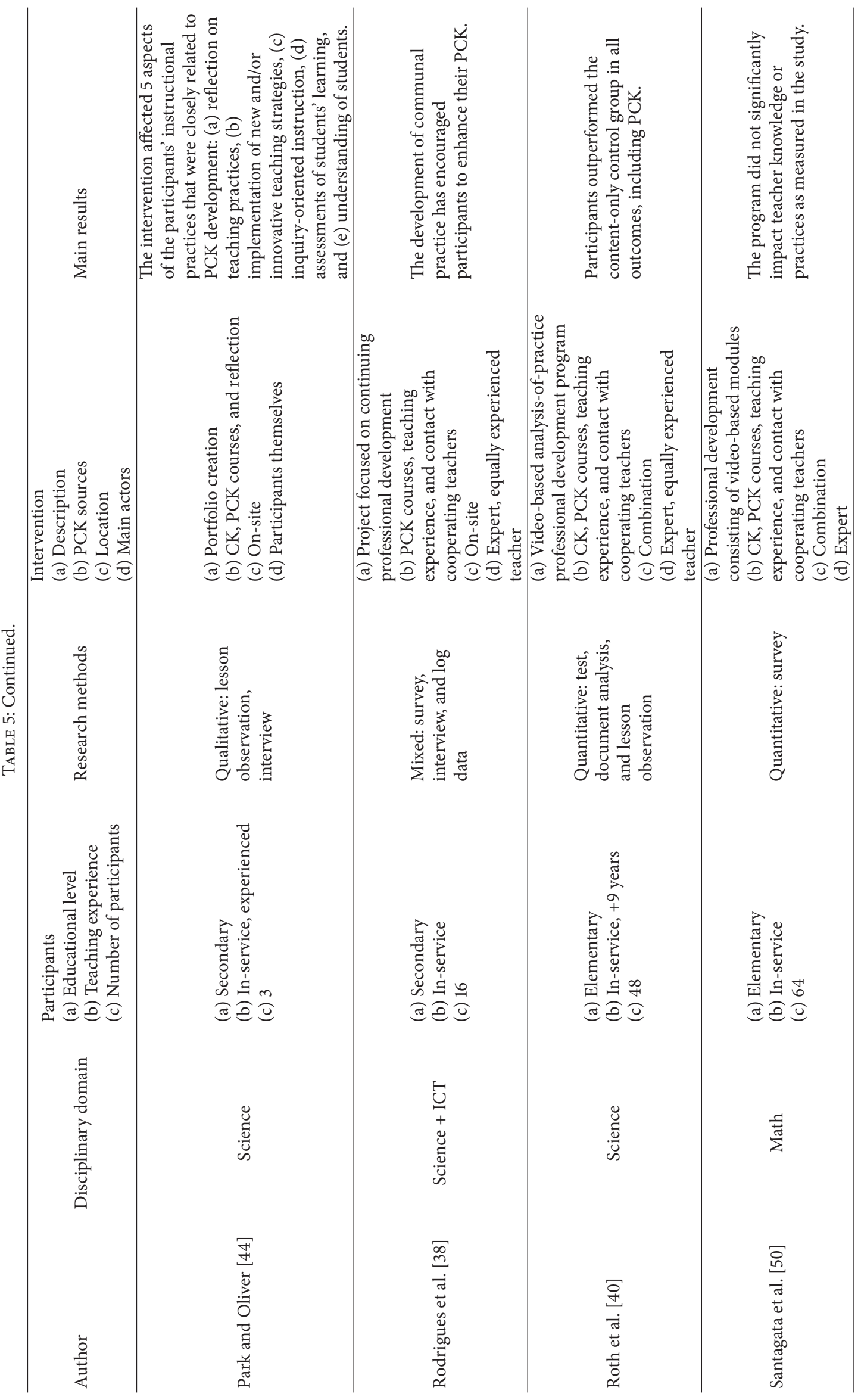




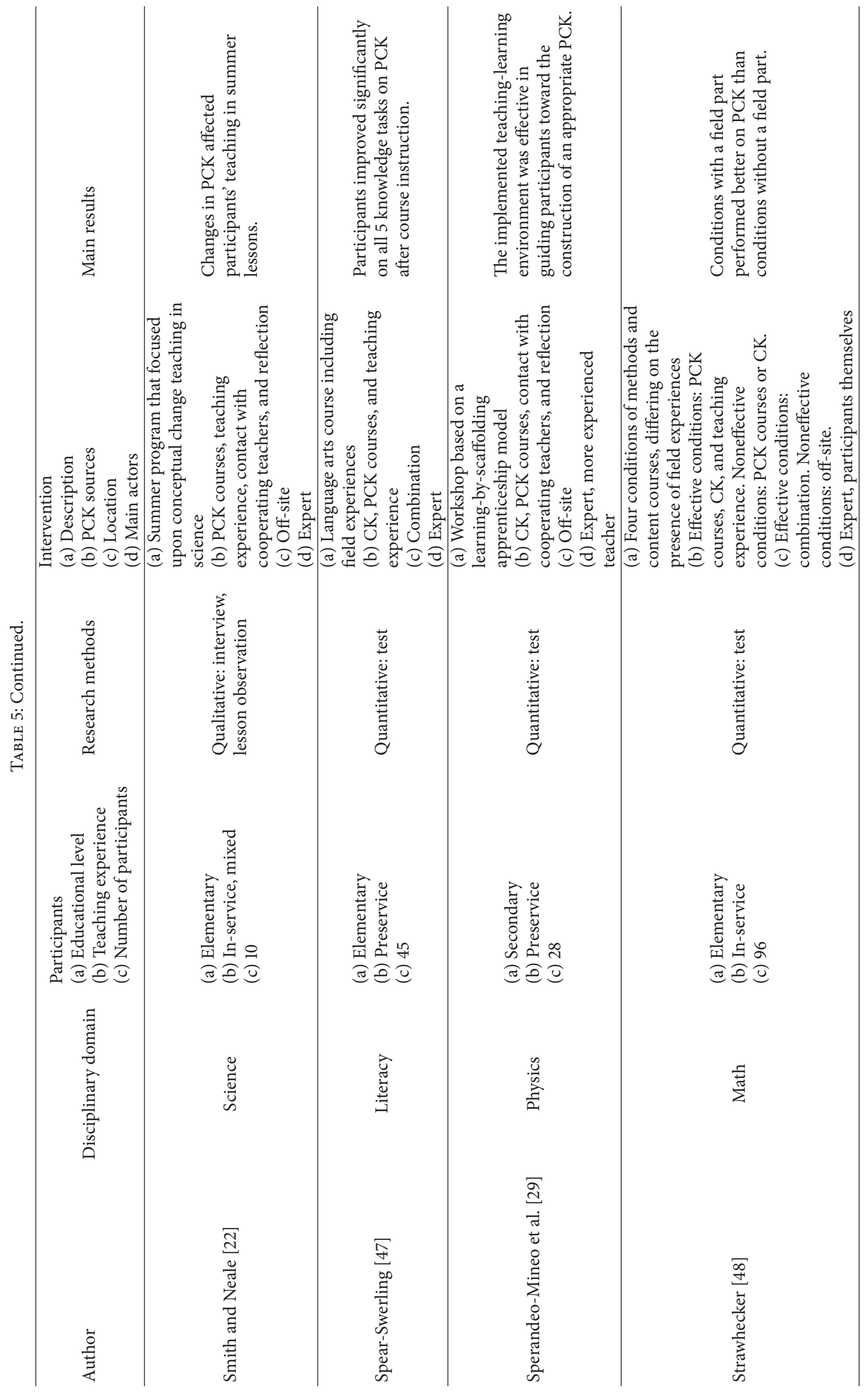




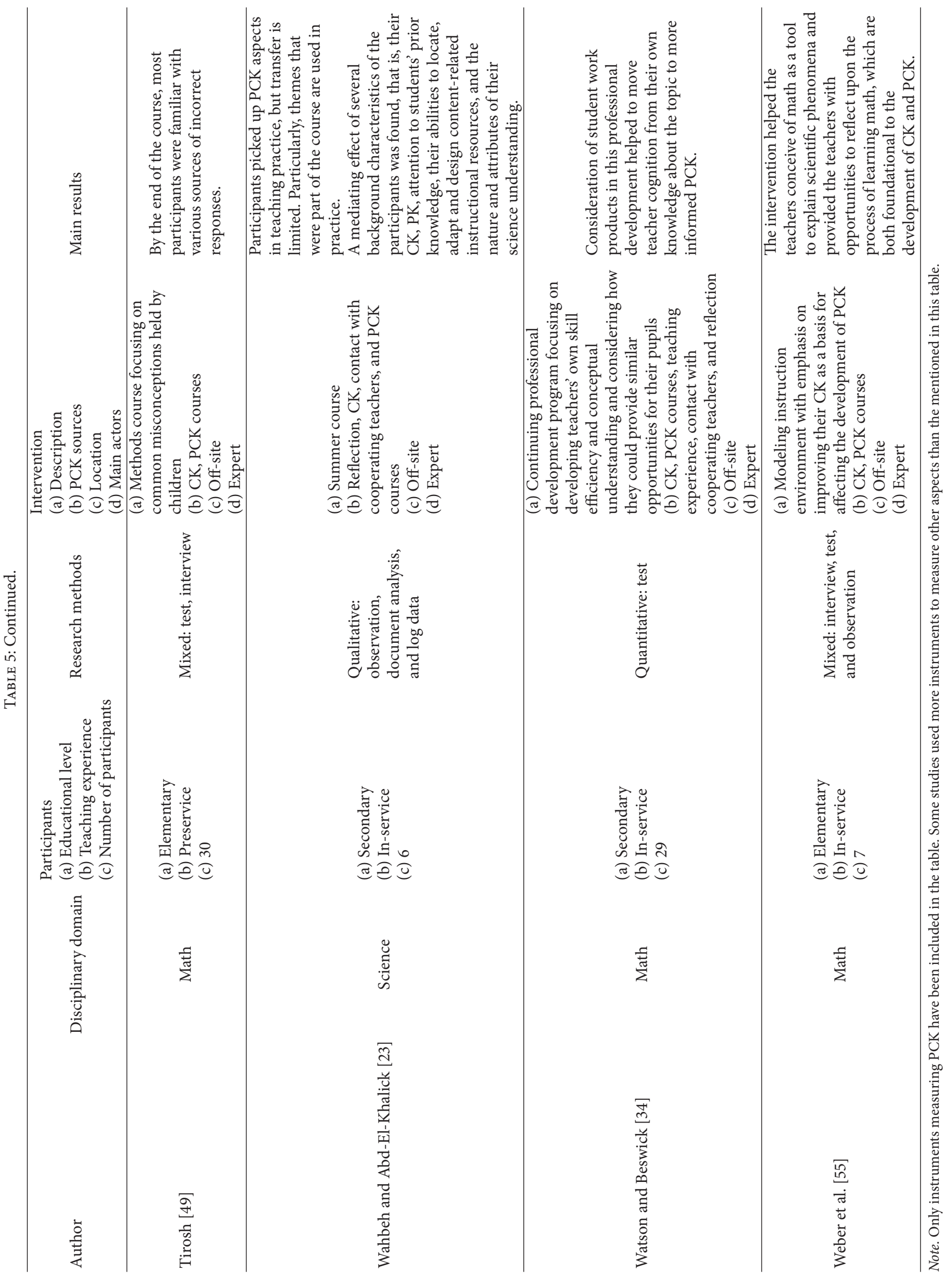


students differed, in disadvantage of the students taking part in the interventions. This problem did not occur in the experimental studies $[20,39,50]$. However, the experimental study of Santagata et al. [50] also did not find positive effects of the intervention on PCK. These authors described several possible reasons. They drew attention to their sample population, which came from a minority environment and had considerably less knowledge than the national average. As there was a lack of support from the school administrators, the participating teachers might not have tried their best when completing the measurement, which may have rendered doubtful results. It seems indicated to be careful in sampling and to look for a representative if one wants to draw conclusions that are generalizable to a large population. As a solution, the authors suggested to assess teachers' knowledge before finalizing the design of the intervention and adapt the intervention to the participants' knowledge level. Furthermore, the authors stressed the importance of sharing the professional development goals with the participants prior to the intervention. This conclusion corresponds to the finding in several effective studies that making the concept PCK explicit to the participants in the beginning of the intervention is beneficial for the effectivity of the intervention.

However, these conclusions should be interpreted cautiously because of several reasons. Firstly, the original meanings of the PCK sources were adapted to the context of the present study. Therefore, the conclusions that are drawn are only related to the adapted meanings of the sources. The authors of the intervention studies did not mention the sources themselves. Secondly, of the 37 studies in the dataset, 35 showed a (partially) positive development in PCK after the intervention. This might mean that most authors who designed interventions did this in a very effective way. However, this result might also be caused by publication bias. "A publication bias exists if the probability that a study reaches the literature and is thus available for combined analysis depends on the results of the study", p. 6 [63]. Studies that did not find a positive effect of an intervention might not have been published. Thirdly, the conclusions of the present study are based on a small dataset. Furthermore, of the 37 articles that are included in the dataset, only three followed an experimental design $[20,39,50]$, and four followed a quasiexperimental design [35, 37, 40, 48]. (Quasi)experimental designs limit the chance of effects to be attributed to extraneous factors. As the majority of the studies in the dataset do not meet the conditions of (quasi)experimental design, it is not sure whether the results that are found in these studies are caused by the interventions or by other variables. Fourthly, researchers mostly stayed rather implicit about their interventions. In most cases, it is not very clear what the interventions exactly comprised. It may be possible that certain sources are addressed in the interventions without being reported. For instance, Monet and Etkina [46] explained that their intervention included teacher-centered and student-centered activities, but they did not further elaborate on these activities.

It would be interesting for further intervention research on PCK to incorporate the following guidelines. Firstly, this review has particularly shown the importance of reflection for PCK development. Further intervention studies are encouraged to include reflection in their interventions. Furthermore, the present study has shown that interventions including courses or exercises on student understanding and educational representations, contact with other teachers, and experiences in educational practice are effective PCK sources. Further interventions could incorporate these elements. Secondly, making PCK explicit to participants in interventions might help them in developing as teachers. Thirdly, course facilitation by experts in the field has been shown to be effective for PCK development. Fourthly, interventions would benefit from a clear conceptualization of PCK. The way in which PCK is operationalized by the different research instruments in the dataset reveals that PCK is understood in different ways. A clear conceptualization, on which PCK instruments are based, might be a sound basis for the systematic design of an intervention. Fifthly, the use of intervention studies that apply experimental designs, compare at least two groups, and use pre- and posttesting [17] to increase the chance that effects are caused by the intervention is advocated. Sixthly, systematic instructional design principles might guide the design of the intervention to be able to exactly find out what parts of the interventions are effective. In any case, additional information is needed on how interventions are designed and what parts they comprise. Seventhly, systematically studying the impact of the different PCK sources would be interesting. Eighthly, since the majority of intervention research on PCK is conducted within the context of the exact sciences, we think it would be interesting for further research to broaden its scope to other disciplinary domains, such as languages or social sciences. Ninthly, we recommend using mixed methodology while studying the effects of educational interventions as this methodology leads to richer, more nuanced results than the use of only quantitative or qualitative methods. Finally, the studies in the dataset did not study the effects of their interventions in the long run. Therefore, it is not sure whether the effects that were found are permanent. Further research is recommended to include retention tests.

\section{Appendix}

See Table 5.

\section{Conflict of Interests}

The authors declare that there is no conflict of interests regarding the publication of this paper.

\section{References}

[1] L. S. Shulman, "Those who understand: knowledge growth in teaching," Educational Researcher, vol. 15, no. 2, pp. 4-14, 1986.

[2] L. S. Shulman, "Knowledge and teaching: foundations of the new reform," Harvard Educational Review, vol. 57, no. 1, pp. 123, 1987.

[3] P. L. Grossman, The Making of a Teacher: Teacher Knowledge and Teacher Education, Teachers College Press, New York, NY, USA, 1990. 
[4] S. Magnusson, J. Krajcik, and H. Borko, "Nature, sources and development of pedagogical content knowledge for science teaching," in Examining Pedagogical Content Knowledge, J. GessNewsome and N. G. Lederman, Eds., pp. 95-132, Kluwer Academic Publishers, Dordrecht, The Netherlands, 1999.

[5] D. L. Ball, M. H. Thames, and G. Phelps, "Content knowledge for teaching: what makes it special?" Journal of Teacher Education, vol. 59, no. 5, pp. 389-407, 2008.

[6] J. Baumert, M. Kunter, W. Blum et al., “Teachers' mathematical knowledge, cognitive activation in the classroom, and student progress," American Educational Research Journal, vol. 47, no. 1, pp. 133-180, 2010.

[7] M. Kunter, U. Klusmann, J. Baumert, D. Richter, T. Voss, and A. Hachfeld, "Professional competence of teachers: effects on instructional quality and student development," Journal of Educational Psychology, vol. 105, no. 3, pp. 805-820, 2013.

[8] W. Haston and A. Leon-Guerrero, "Sources of pedagogical content knowledge: reports by preservice instrumental music teachers," Journal of Music Teacher Education, vol. 17, pp. 48-59, 2008.

[9] V. Kind, "Pedagogical content knowledge in science education: perspectives and potential for progress," Studies in Science Education, vol. 45, no. 2, pp. 169-204, 2009.

[10] J. van Driel and N. Verloop, “'Pedagogical content knowledge': a unifying element in the knowledge base of teachers," Pedagogische Studiën, vol. 75, pp. 225-237, 1998.

[11] P. E. Simmons, A. Emory, T. Carter et al., "Beginning teachers: beliefs and classroom actions," Journal of Research in Science Teaching, vol. 36, no. 8, pp. 930-954, 1999.

[12] P. J. Friedrichsen, S. K. Abell, E. M. Pareja, P. L. Brown, D. M. Lankford, and M. J. Volkmann, "Does teaching experience matter? Examining biology teachers' prior knowledge for teaching in an alternative certification program," Journal of Research in Science Teaching, vol. 46, no. 4, pp. 357-383, 2009.

[13] J. Brownlee, N. Purdie, and G. Boulton-Lewis, "Changing epistemological beliefs in pre-service teacher education students," Teaching in Higher Education, vol. 6, pp. 247-268, 2001.

[14] D. C. Lortie, Schoolteacher: A Sociological Study, University of Chicago Press, Chicago, Ill, USA, 1975.

[15] R. Kenney, M. Shoffner, and D. Norris, "Reflecting to learn mathematics: supporting pre-service teachers' pedagogical content knowledge with reflection on writing prompts in mathematics education," Reflective Practice: International and Multidisciplinary Perspectives, vol. 14, no. 6, pp. 787-800, 2013.

[16] M. Petticrew and H. Roberts, Systematic Reviews in the Social Sciences: A Practical Guide, Blackwell Publishing, Oxford, UK, 2006.

[17] J. Hattie, J. Biggs, and N. Purdie, "Effects of learning skills interventions on student learning: a meta-analysis," Review of Educational Research, vol. 66, no. 2, pp. 99-136, 1996.

[18] M. B. Miles and A. M. Huberman, Qualitative Data Analysis, Sage, Thousand Oaks, Calif, USA, 2nd edition, 1994.

[19] F. Arbaugh and C. A. Brown, "Analyzing mathematical tasks: a catalyst for change?" Journal of Mathematics Teacher Education, vol. 8, no. 6, pp. 499-536, 2005.

[20] S. Dash, R. M. de Kramer, L. M. O’Dwyer, J. Masters, and M. Russell, "Impact of online professional development on teacher quality and student achievement in fifth grade mathematics," Journal of Research on Technology in Education, vol. 45, no. 1, pp. 1-26, 2012.
[21] O. De Jong and J. van Driel, "Exploring the development of student teachers' PCK of the multiple meanings of chemistry topics," International Journal of Science and Mathematics Education, vol. 2, no. 4, pp. 477-491, 2004.

[22] D. C. Smith and D. C. Neale, "The construction of subject matter knowledge in primary science teaching," Teaching \& Teacher Education, vol. 5, no. 1, pp. 1-20, 1989.

[23] N. Wahbeh and F. Abd-El-Khalick, "Revisiting the translation of nature of science understandings into instructional practice: teachers' nature of science pedagogical content knowledge," International Journal of Science Education, vol. 36, no. 3, pp. 425-466, 2014.

[24] E. P. Burton, "Student work products as a teaching tool for nature of science pedagogical knowledge: a professional development project with in-service secondary science teachers," Teaching and Teacher Education, vol. 29, no. 1, pp. 156-166, 2013.

[25] S. J. Derry, M. J. Wilsman, and A. J. Hackbarth, "Using contrasting case activities to deepen teacher understanding of algebraic thinking and teaching," Mathematical Thinking and Learning, vol. 9, no. 3, pp. 305-329, 2007.

[26] R. Justi and J. van Driel, "A case study of the development of a beginning chemistry teacher's knowledge about models and modelling," Research in Science Education, vol. 35, no. 2-3, pp. 197-219, 2005.

[27] D. E. Kanter and S. Konstantopoulos, “The impact of a projectbased science curriculum on minority student achievement, attitudes, and careers: the effects of teacher content and pedagogical content knowledge and inquiry-based practices," Science Education, vol. 94, no. 5, pp. 855-887, 2010.

[28] C. Khourey-Bowers and C. Fenk, "Influence of constructivist professional development on chemistry content knowledge and scientific model development," Journal of Science Teacher Education, vol. 20, no. 5, pp. 437-457, 2009.

[29] R. M. Sperandeo-Mineo, C. Fazio, and G. Tarantino, "Pedagogical content knowledge development and pre-service physics teacher education: a case study," Research in Science Education, vol. 36, no. 3, pp. 235-268, 2006.

[30] R. Justi and J. van Driel, “The development of science teachers' knowledge on models and modelling: promoting, characterizing, and understanding the process," International Journal of Science Education, vol. 27, no. 5, pp. 549-573, 2005.

[31] S. Aydin, B. Demirdogen, A. Tarkin et al., "Providing a set of research-based practices to support preservice teachers' longterm professional development as learners of science teaching," Science Education, vol. 97, no. 6, pp. 903-935, 2013.

[32] S. Aydin, B. Demirdogen, F. Nur Akin, E. UzuntiryakiKondakci, and A. Tarkin, "The nature and development of interaction among components of pedagogical content knowledge in practicum," Teaching and Teacher Education, vol. 46, pp. 37-50, 2015.

[33] K. Goodnough and W. Hung, "Enhancing pedagogical content knowledge in elementary science," Teaching Education, vol. 20, no. 3, pp. 229-242, 2009.

[34] J. W. Watson and K. B. Beswick, "School pupil change associated with a continuing professional development programme for teachers," Journal of Education for Teaching, vol. 37, no. 1, pp. 63-75, 2011.

[35] N. Buchholtz and G. Kaiser, "Improving mathematics teacher education in Germany: empirical results from a longitudinal evaluation of innovative programs," International Journal of Science and Mathematics Education, vol. 11, no. 4, pp. 949-977, 2013. 
[36] C. J. Beyer and E. A. Davis, "Learning to critique and adapt science curriculum materials: examining the development of preservice elementary teachers' pedagogical content knowledge," Science Education, vol. 96, no. 1, pp. 130-157, 2012.

[37] T. Michalsky, "Shaping self-regulation in science teachers' professional growth: inquiry skills," Science Education, vol. 96, no. 6, pp. 1106-1133, 2012.

[38] S. Rodrigues, A. Marks, and P. Steel, "Developing science and ICT pedagogical content knowledge: a model of continuing professional development," Innovations in Education and Teaching International, vol. 40, no. 4, pp. 386-394, 2003.

[39] N. Harr, A. Eichler, and A. Renkl, "Integrating pedagogical content knowledge and pedagogical/psychological knowledge in mathematics," Frontiers in Psychology, vol. 5, article 924, 10 pages, 2014.

[40] K. J. Roth, H. E. Garnier, C. Chen, M. Lemmens, K. Schwille, and N. I. Z. Wickler, "Videobased lesson analysis: effective science PD for teacher and student learning," Journal of Research in Science Teaching, vol. 48, no. 2, pp. 117-148, 2011.

[41] R. M. Capraro, M. M. Capraro, D. Parker, G. Kulm, and T. Raulerson, "The mathematics content knowledge role in developing preservice teachers' pedagogical content knowledge," Journal of Research in Childhood Education, vol. 20, no. 2, pp. 102-118, 2005.

[42] J. A. Luft, J. B. Firestone, S. S. Wong, I. Ortega, K. Adams, and E. Bang, "Beginning secondary science teacher induction: a two-year mixed methods study," Journal of Research in Science Teaching, vol. 48, no. 10, pp. 1199-1224, 2011.

[43] S.-J. Jang, "Assessing college students' perceptions of a case teacher's pedagogical content knowledge using a newly developed instrument," Higher Education, vol. 61, no. 6, pp. 663-678, 2011.

[44] S. Park and J. S. Oliver, "National Board Certification (NBC) as a catalyst for teachers' learning about teaching: the effects of the NBC process on candidate teachers' PCK development," Journal of Research in Science Teaching, vol. 45, no. 7, pp. 812-834, 2008.

[45] J. D. Davis, "Understanding the influence of two mathematics textbooks on prospective secondary teachers' knowledge," Journal of Mathematics Teacher Education, vol. 12, no. 5, pp. 365-389, 2009.

[46] J. A. Monet and E. Etkina, "Fostering self-reflection and meaningful learning: earth science professional development for middle school science teachers," Journal of Science Teacher Education, vol. 19, no. 5, pp. 455-475, 2008.

[47] L. Spear-Swerling, "A literacy tutoring experience for prospective special educators and struggling second graders," Journal of Learning Disabilities, vol. 42, no. 5, pp. 431-443, 2009.

[48] J. Strawhecker, "Preparing elementary teachers to teach mathematics: how field experiences impact pedagogical content knowledge," The Journal, vol. 4, pp. 1-12, 2005.

[49] D. Tirosh, "Enhancing prospective teachers' knowledge of children's conceptions: the case of division of fractions," Journal for Research in Mathematics Education, vol. 31, no. 1, pp. 5-25, 2000.

[50] R. Santagata, N. Kersting, K. B. Givvin, and J. W. Stigler, "Problem implementation as a lever for change: an experimental study of the effects of a professional development program on students' mathematics learning," Journal of Research on Educational Effectiveness, vol. 4, no. 1, pp. 1-24, 2010.
[51] K. L. McNeill and A. M. Knight, “Teachers' pedagogical content knowledge of scientific argumentation: the impact of professional development on K-12 teachers," Science Education, vol. 97, no. 6, pp. 936-972, 2013.

[52] O. De Jong, J. H. van Driel, and N. Verloop, "Preservice teachers' pedagogical content knowledge of using particle models in teaching chemistry," Journal of Research in Science Teaching, vol. 42, no. 8, pp. 947-964, 2005.

[53] P. Nilsson and J. Loughran, "Exploring the development of pre-service science elementary teachers' pedagogical content knowledge," Journal of Science Teacher Education, vol. 23, no. 7, pp. 699-721, 2012.

[54] B. M. Kinach, "A cognitive strategy for developing pedagogical content knowledge in the secondary mathematics methods course: toward a model of effective practice," Teaching and Teacher Education, vol. 18, no. 1, pp. 51-71, 2002.

[55] E. Weber, M. A. Tallman, and J. A. Middleton, "Developing elementary teachers' knowledge about functions and rate of change through modeling," Mathematical Thinking and Learning, vol. 17, no. 1, pp. 1-33, 2015.

[56] P. Grossman and S. Stodolsky, "Content as context: the role of school subjects in secondary school teaching," Educational Researcher, vol. 24, pp. 5-11, 1995.

[57] J. H. van Driel and A. Berry, "Teacher professional development focusing on pedagogical content knowledge," Educational Researcher, vol. 41, no. 1, pp. 26-28, 2012.

[58] D. McIntyre, "Theory, theorizing and reflection in initial teacher education," in Conceptualizing Reflection in Teacher Development, J. Calderhead and P. James, Eds., pp. 39-52, The Falmer Press, London, UK, 1993.

[59] T. Wubbels and F. A. J. Korthagen, "The effects of a preservice teacher education program for the preparation of reflective teachers," Journal of Education for Teaching: International Research and Pedagogy, vol. 16, no. 1, pp. 29-43, 1990.

[60] H. M. Chae, J. H. Kim, and M. Glass, "Effective behaviors in a comparison between novice and expert algebra tutors," in Proceedings of the Modern Artificial Intelligence and Cognitive Science Conference, Dayton, Ohio, USA, April 2005.

[61] L. B. Couto, R. B. Bestetti, C. B. Restini, M. Faria Jr., and G. S. Romão, "Brazilian medical students' perceptions of expert versus non-expert facilitators in a (non) problem-based learning environment," Medical Education Online, vol. 20, Article ID 26893, 2015.

[62] C. Dignath, G. Buettner, and H.-P. Langfeldt, "How can primary school students learn self-regulated learning strategies most effectively?: a meta-analysis on self-regulation training programmes," Educational Research Review, vol. 3, no. 2, pp. 101-129, 2008.

[63] J. D. Scargle, "Publication bias (the 'file-drawer problem') in scientific inference," in Proceedings of the Sturrock Symposium, Stanford University, March 1999.

[64] A. Hume and A. Berry, "Enhancing the practicum experience for pre-service chemistry teachers through collaborative CoRe design with mentor teachers," Research in Science Education, vol. 43, no. 5, pp. 2107-2136, 2013.

[65] A. Hume, "Promoting higher levels of reflective writing in student journals," Higher Education Research \& Development, vol. 28, no. 3, pp. 247-260, 2009.

[66] A. C. Hume, "Primary connections: simulating the classroom in initial teacher education," Research in Science Education, vol. 42, no. 3, pp. 551-565, 2012. 
[67] R. Mamlok-Naaman, R. Blonder, and A. Hofstein, "Providing chemistry teachers with opportunities to enhance their knowledge in contemporary scientific areas: a three-stage model," Chemistry Education Research and Practice, vol. 11, no. 4, pp. 241-252, 2010.

[68] B.-S. Eylon and E. Bagno, "Research-design model for professional development of teachers: designing lessons with physics education research," Physical Review Special Topics-Physics Education Research, vol. 2, no. 2, Article ID 020106, 2006.

[69] L. Halim, N. A. Buanga, and T. S. Meeraha, "Action research as instructional supervision: impact on the professional development of university based supervisors and science student teachers," Procedia-Social and Behavioral Sciences, vol. 2, no. 2, pp. 2868-2871, 2010.

[70] S.-J. Jang, M.-F. Tsai, and H.-Y. Chen, "Development of PCK for novice and experienced university physics instructors: a case study," Teaching in Higher Education, vol. 18, no. 1, pp. 27-39, 2013.

[71] R. Rozenszajn and A. Yarden, "Expansion of biology teachers' pedagogical content knowledge (PCK) during a long-term professional development program," Research in Science Education, vol. 44, no. 1, pp. 189-213, 2014.

[72] K. Appleton, "Developing science pedagogical content knowledge through mentoring elementary teachers," Journal of Science Teacher Education, vol. 19, no. 6, pp. 523-545, 2008.

[73] B. Gustafson, S. Guilbert, and D. MacDonald, "Beginning elementary science teachers: developing professional knowledge during a limited mentoring experience," Research in Science Education, vol. 32, no. 3, pp. 281-302, 2002.

[74] Y. Lee, "Enhancing pedagogical content knowledge in a collaborative school-based professional development program for inquiry-based science teaching," Asia-Pacific Forum on Science Learning and Teaching, vol. 12, no. 2, article 3, 2011.

[75] P. Nilsson and J. van Driel, "Teaching together and learning together: primary science student teachers' and their mentors' joint teaching and learning in the primary classroom," Teaching and Teacher Education, vol. 26, no. 6, pp. 1309-1318, 2010.

[76] P. Nilsson, "What do we know and where do we go? Formative assessment in developing student teachers' professional learning of teaching science," Teachers and Teaching, vol. 19, no. 2, pp. 195-208, 2013.

[77] R. M. Schneider, "Opportunities for teacher learning during enactment of inquiry science curriculum materials: exploring the potential for teacher educative materials," Journal of Science Teacher Education, vol. 24, no. 2, pp. 323-346, 2013.

[78] C. Zembal-Saul, P. Blumenfeld, and J. Krajcik, "Influence of guided cycles of planning, teaching, and reflection on prospective elementary teachers' science content representations," Journal of Research in Science Teaching, vol. 37, no. 4, pp. 318-339, 2000.

[79] J. J. Watters and L. S. Ginns, "An in-depth study of a teacher engaged in an innovative primary science trial professional development project," Research in Science Education, vol. 27, no. 1, pp. 51-69, 1997.

[80] A. Bertram and J. Loughran, "Science teachers' views on CoRes and PaP-eRs as a framework for articulating and developing pedagogical content knowledge," Research in Science Education, vol. 42, no. 6, pp. 1027-1047, 2012.

[81] N. Halai and M. A. Khan, "Developing pedagogical content knowledge of science teachers through action research: a case study from Pakistan," Asia-Pacific Forum on Science Learning and Teaching, vol. 12, no. 1, pp. 1-23, 2011.
[82] A. Hume and A. Berry, "Constructing CoRes-a strategy for building PCK in pre-service science teacher education," Research in Science Education, vol. 41, no. 3, pp. 341-355, 2011.

[83] J. Oshima, R. Horino, R. Oshima et al., "Changing teachers' epistemological perspectives: a case study of teacher-researcher collaborative lesson studies in Japan," Teaching Education, vol. 17, no. 1, pp. 43-57, 2006.

[84] J. H. van Driel, N. Verloop, and W. De Vos, "Developing science teachers' pedagogical content knowledge," Journal of Research in Science Teaching, vol. 35, no. 6, pp. 673-695, 1998.

[85] S. Dotger, "Exploring and developing graduate teaching assistants' pedagogies via lesson study," Teaching in Higher Education, vol. 16, no. 2, pp. 157-169, 2011.

[86] K. Goodnough, "Enhancing pedagogical content knowledge through self-study: an exploration of problem-based learning," Teaching in Higher Education, vol. 11, no. 3, pp. 301-318, 2006.

[87] P. Osmonda and K. Goodnoughb, "Adopting just-in-time teaching in the context of an elementary science education methodology course," Studying Teacher Education, vol. 7, no. 1, pp. 77-91, 2011.

[88] D. Tirosh, P. Tsamir, E. Levenson, and M. Tabach, "From preschool teachers' professional development to children's knowledge: comparing sets," Journal of Mathematics Teacher Education, vol. 14, no. 2, pp. 113-131, 2011.

[89] S. Abramovich and E. K. Cho, "Mathematics, computers, and young children as a research-oriented learning environment for a teacher candidate," Asia Pacific Education Review, vol. 10, no. 2, pp. 247-259, 2009.

[90] P.-J. Lin, "Using research-based video-cases to Help preservice primary teachers conceptualize a contemporary view of mathematics teaching," International Journal of Science and Mathematics Education, vol. 3, no. 3, pp. 351-377, 2005.

[91] S. Y. Imre and H. Akkoç, "Investigating the development of prospective mathematics teachers' pedagogical content knowledge of generalising number patterns through school practicum," Journal of Mathematics Teacher Education, vol. 15, no. 3, pp. 207-226, 2012.

[92] O. F. Jenkins, "Developing teachers' knowledge of students as learners of mathematics through structured interviews," Journal of Mathematics Teacher Education, vol. 13, no. 2, pp. 141-154, 2010.

[93] K. Koellner, J. Jacobs, H. Borko et al., "The problem-solving cycle: a model to support the development of teachers' professional knowledge," Mathematical Thinking and Learning, vol. 9, no. 3, pp. 273-303, 2007.

[94] R. Leikin, "The wholes that are greater than the sum of their parts: employing cooperative learning in mathematics teachers' education," Journal of Mathematical Behavior, vol. 23, no. 2, pp. 223-256, 2004.

[95] A. Peng, "Knowledge growth of mathematics teachers during professional activity based on the task of lesson explaining," Journal of Mathematics Teacher Education, vol. 10, no. 4-6, pp. 289-299, 2007.

[96] J. R. Seymour and R. Lehrer, "Tracing the evolution of pedagogical content knowledge as the development of interanimated discourses," Journal of the Learning Sciences, vol. 15, no. 4, pp. 549-582, 2006.

[97] J. M. Jenkins and M. L. Veal, "Preservice teachers' PCK development during peer coaching," Journal of Teaching in Physical Education, vol. 22, no. 1, pp. 49-68, 2002. 
[98] I. C. Rovegno, "Learning to teach in a field-based methods course: the development of pedagogical content knowledge," Teaching and Teacher Education, vol. 8, no. 1, pp. 69-82, 1992.

[99] D. Hunuk, M. L. Ince, and D. Tannehill, "Developing teachers' health-related fitness knowledge through a community of practice: impact on student learning," European Physical Education Review, vol. 19, pp. 3-20, 2013.

[100] D. L. Brody and H. Cohen, “'Touch it lightly': Israeli students' construction of pedagogical paradigms about an emotionally laden topic," Journal of Early Childhood Teacher Education, vol. 33, no. 3, pp. 269-286, 2012.

[101] M. B. Henning and D. Yendol-Hoppey, "Context in methods course learning: lessons for partnership work," Teaching Education, vol. 15, pp. 401-416, 2004.

[102] D. Polly, "Teachers' learning while constructing technologybased instructional resources," British Journal of Educational Technology, vol. 42, no. 6, pp. 950-961, 2011.

[103] R. R. Kelani and C. Khourey-Bowers, "Professional development in sub-Saharan Africa: what have we learned in Benin?" Professional Development in Education, vol. 38, no. 5, pp. 705723, 2012.

[104] J. E. Ormrod and D. B. Cole, "Teaching content knowledge and pedagogical content knowledge: a model from geographic education," Journal of Teacher Education, vol. 47, no. 1, pp. 37-42, 1996.

[105] L. E. Shanahan and A. L. Tochelli, "Examining the use of video study groups for developing literacy pedagogical content knowledge of critical elements of strategy instruction with elementary teachers," Literacy Research and Instruction, vol. 53, no. 1, pp. 1-24, 2014.

[106] A. T. Smith and N. A. Place, "Fostering teaching and learning through an inquiry-based literacy methods course," The New Educator, vol. 7, no. 4, pp. 305-324, 2011.

[107] E. Bentley, "Supernovas and superheroes: examining unfamiliar genres and teachers' pedagogical content knowledge," English Education, vol. 45, no. 3, pp. 218-246, 2013.

[108] B. Achinstein and B. Fogo, "Mentoring novices' teaching of historical reasoning: opportunities for pedagogical content knowledge development through mentor-facilitated practice," Teaching and Teacher Education, vol. 45, pp. 45-58, 2015.

[109] J. Williams, C. Eames, A. Hume, and J. Lockley, "Promoting pedagogical content knowledge development for early career secondary teachers in science and technology using content representations," Research in Science and Technological Education, vol. 30, no. 3, pp. 327-343, 2012.

[110] C. H. Major and B. Palmer, "Reshaping teaching and learning: the transformation of faculty pedagogical content knowledge," Higher Education, vol. 51, no. 4, pp. 619-647, 2006.

[111] Y.-R. Juang, T.-C. Liu, and T.-W. Chan, "Computer-supported teacher development of pedagogical content knowledge through developing school-based curriculum," Educational Technology and Society, vol. 11, no. 2, pp. 149-170, 2008. 

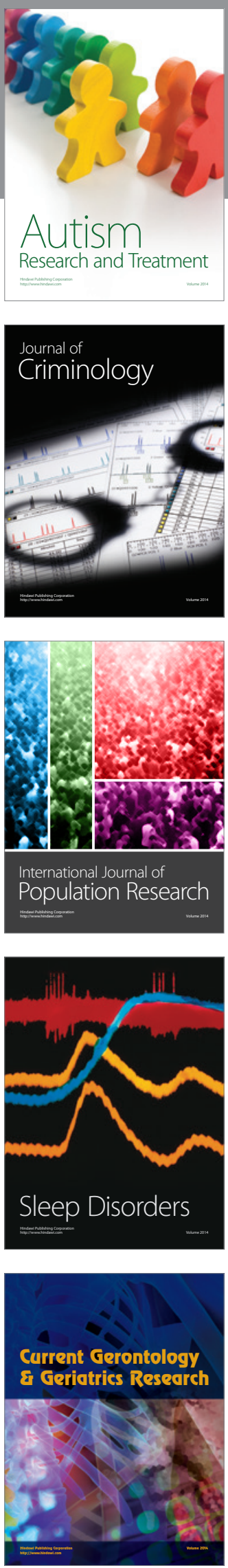
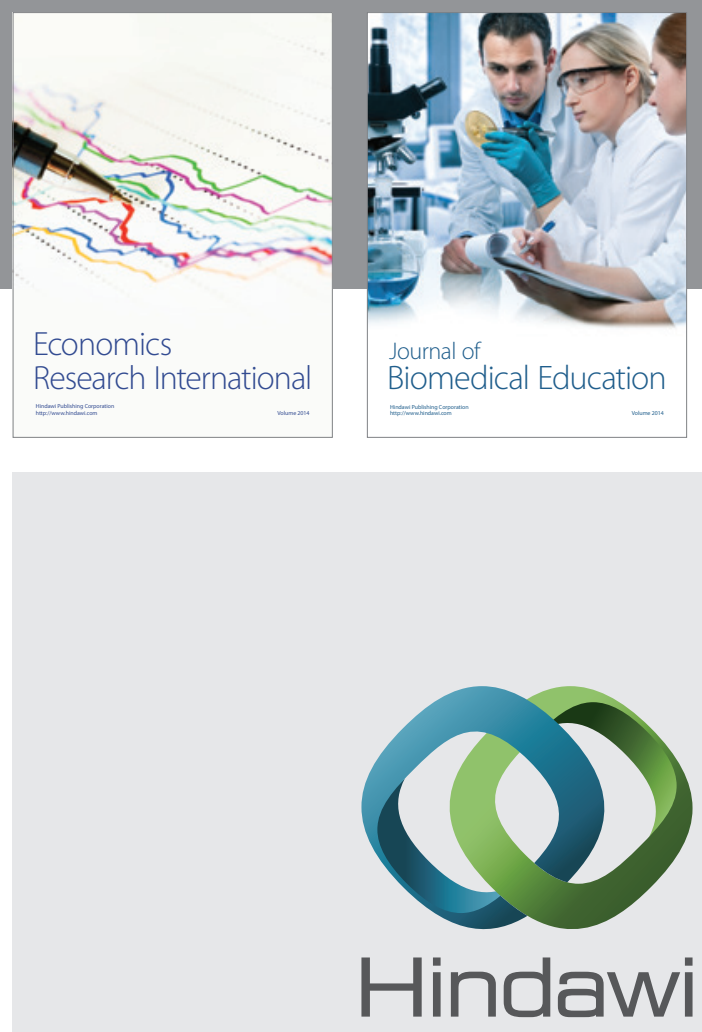

Submit your manuscripts at

http://www.hindawi.com
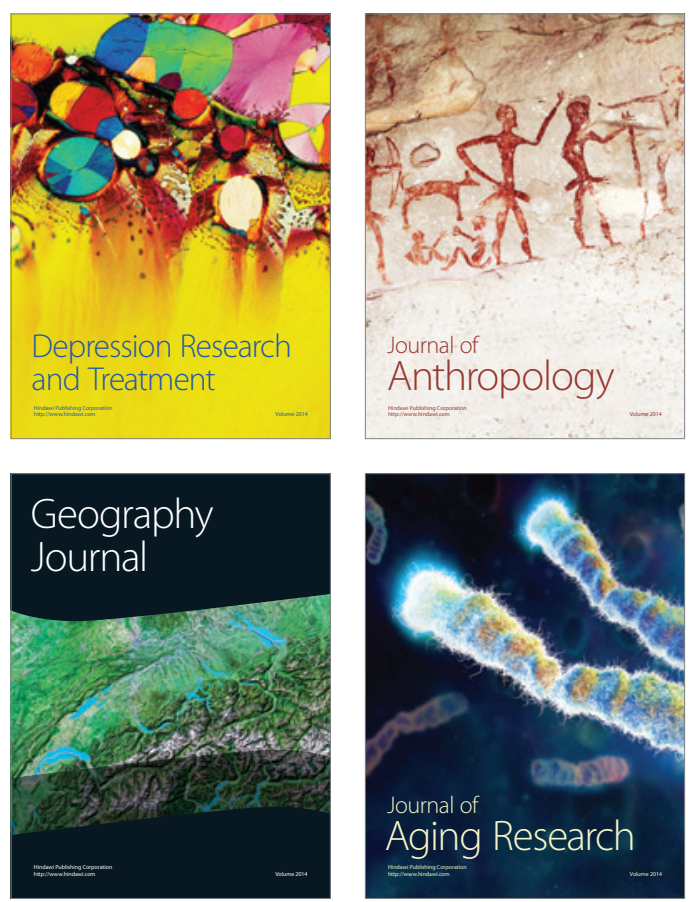
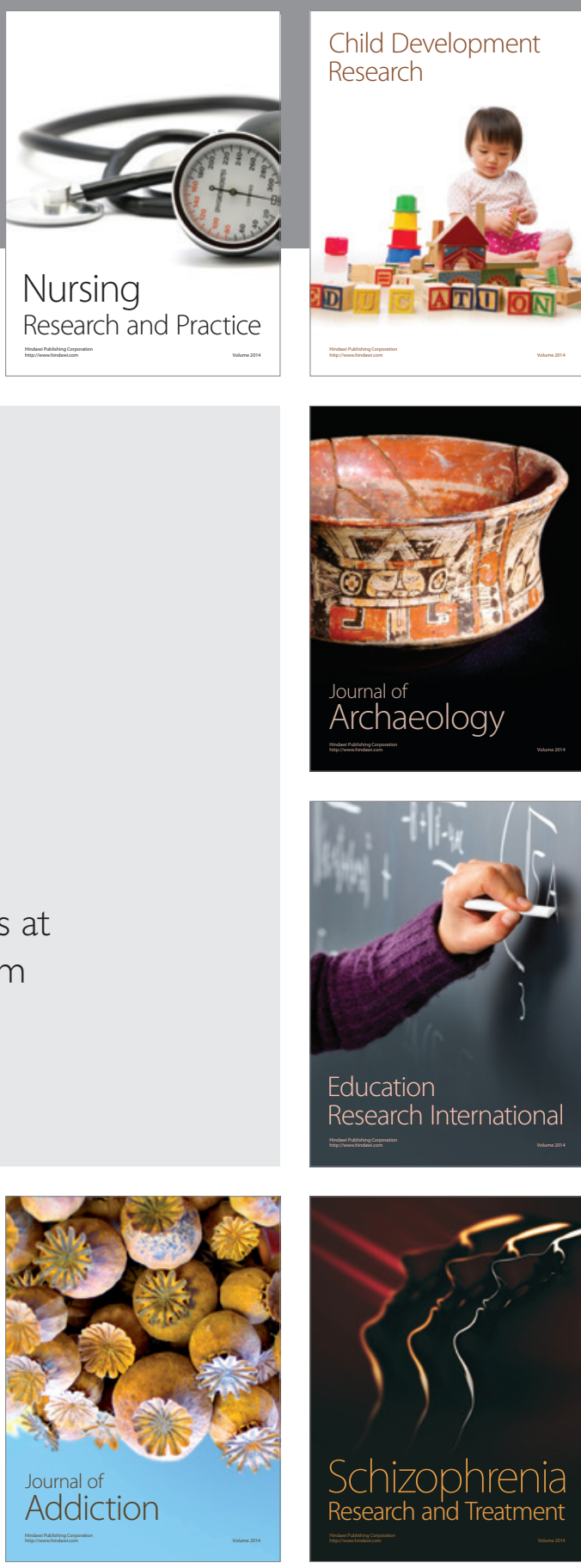

(D)
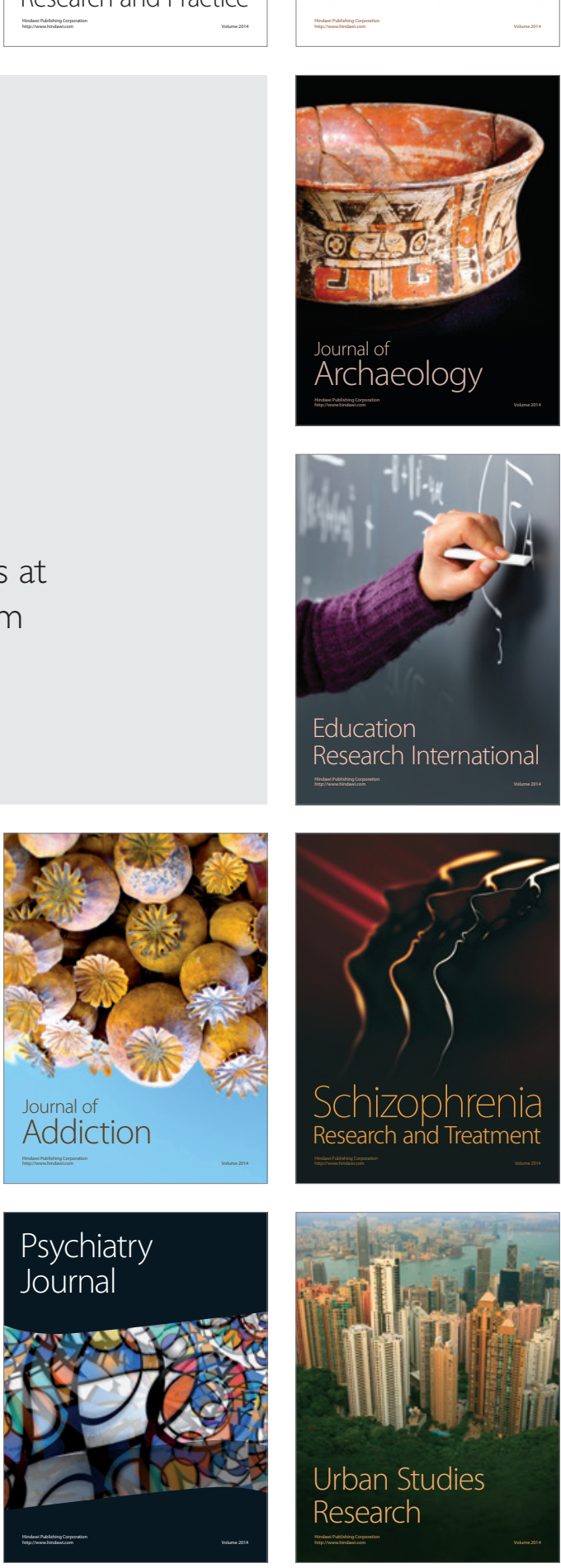